\title{
معوقات التنمية المهنية لمعلمي التربية الخاصة \\ ومتطلبات مواجهتها
}

\section{زينب ابراهيه على محمد}

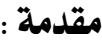

و التحديث ومهما اســتخدمت مــن وســائل

يعد المعلم الركيزة الأهم في العمليــة

متطورة ومعاصرة وطبقت الخطط و البر امج وماتج

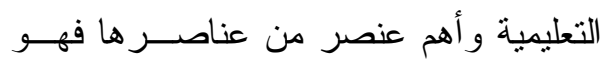

التعليمية الفاعلة دون الاهنمام والتركيز علي وماهرة وطئ الموجه و المنفذ لها، كما أنه العنصر الفعــال

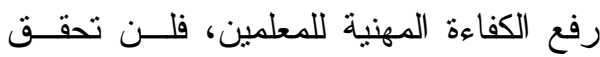
في تحقيق الأهداف التزبوية المنشودة؛ لـــللك

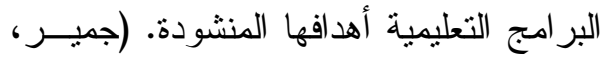
يجب الاهتمام بتتميته مهنيًا حتهى يسـستطيع $(9 .-10$ ، $4 . .5$

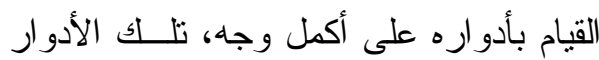
ولأن التتمية المهنية هي الوجه المكمل

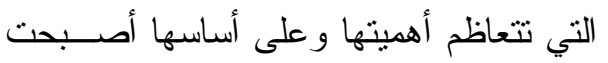
لعملية إعداد المعلمين، لذا تحظــى التتميــة

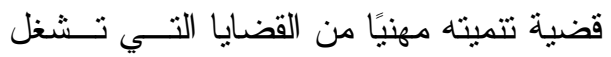
المهنية للمعلمين باهتمام الأنظمة التعليمية في

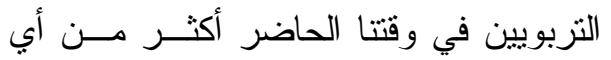

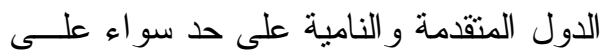
وقت مضى بسبب التغير ات التي طر أت على ولى أساس أنها عملية تقدمية تـستهدف الطاقــة المجتمع وكان لها التأثير الأكبر على العملية البشرية بالإعداد و التوجيه وضمان استمرار التعليمية. تتميتها وتطور ها بشكل فعال، كما تـستهدف

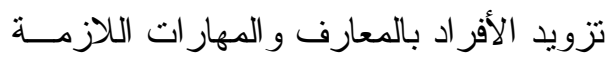
ومن هذا المنطلق يحتاج المعلم إلـى

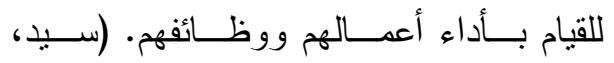
تطوير كفاياته العلمية والتزبوية ومو اكبة كل جديد ومنطور عن طريــق أســاليب الــتعلم

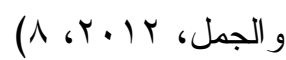

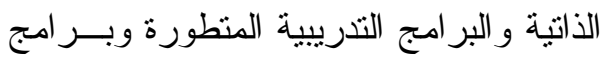
و إذا كانت التتمية المهنية للمعلم بشكل التنريب أثناء الخدمة و التي تعتبر مطلب هام

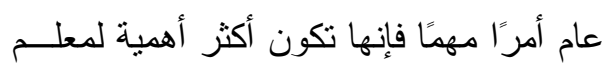

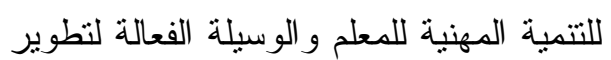
التربية الخاصة، حيث فرضت تحدياتها على الى التهاه

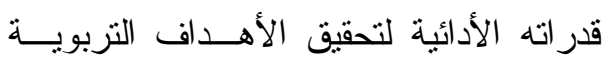
معلم التربية الخاصة مما يستلزم إعادة النظر

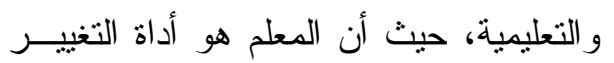

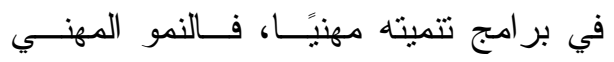

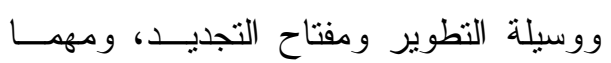

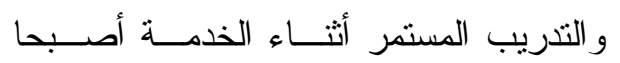

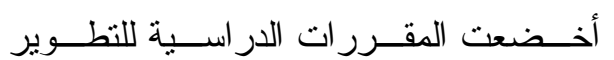


في مختلف المجالات، وهذا الاهتمام ينصب أو لا على معلم التزبيـــة الخاصـــة باعتبـــاره الركيزة الأساسية في العملية التعليمية. ولما كان إصلاح التعليم وتطويره لابد

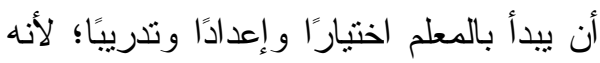

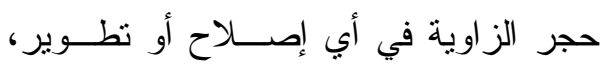

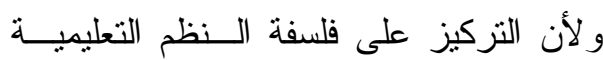
بأهدافها ومناهجها لا يمكن أن تؤدي بمفردها

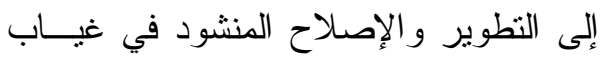
المعلم المقتدر ذي الكفـــاءة العاليـــة و الأداء

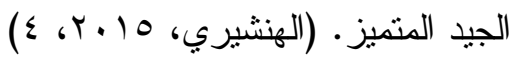
وعلى الرغم من كل الجهــود التـي

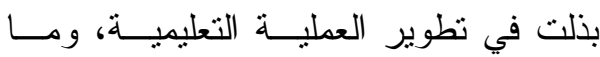

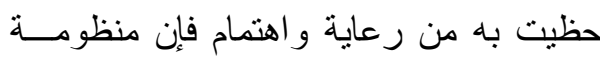

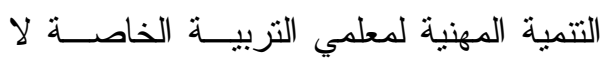

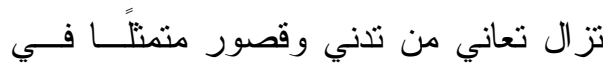

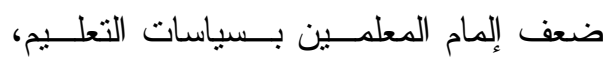

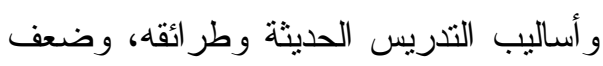
الإمكانات البشرية و المادية للإدار ات العامـــة وطئة

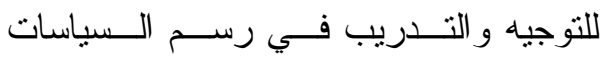
و الخطط وتتفيذها و عدم قدرتها على تغطيــة

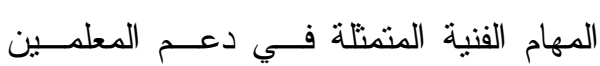

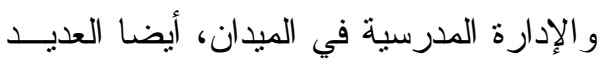
من معلمي التربية الخاصة غيــر مـــؤهلين

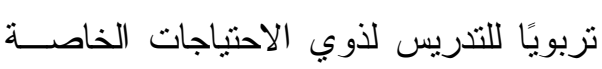

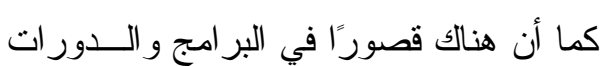

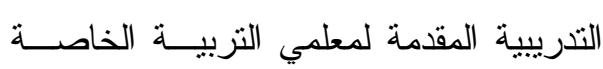

أمرين حتميين لتجديد خبرات معلم التزبيـــة الخاصة خاصة مع بروز القضايا المرتبطــــة

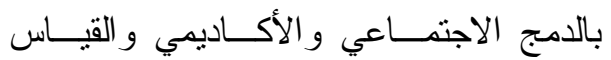

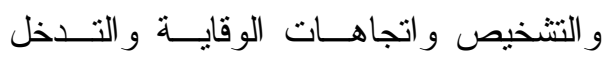

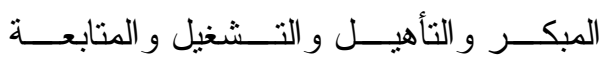

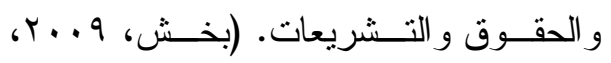
(I TV-I KY وبنظرة تحليلية لو اقع التتمية المهنيــة

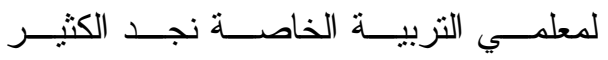
من المعوقات كالاعتماد على صيغ محــددة في بر امج التتمية المهنية، وغيــاب التقــويم

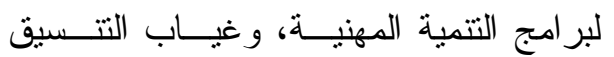
بين مدارس التربية الخاصة وكليات التربيـــة

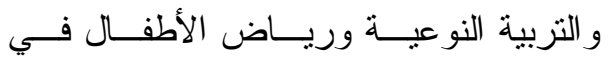
مجال التتمية المهنية ومن هنا جاءت فكـرة ورئ البحث. مشكلة البحث: أضـــــت رعايــــة ذوي الاحتياجــات الخاصة وتعليمهم بما يلائم قدر اتهم ضرورة حتمية و استر اتيجية مهمة تسار ع إليه الكثيـــر من الدول للاهتمام بفئات الإعاقة كما تعدـلـل

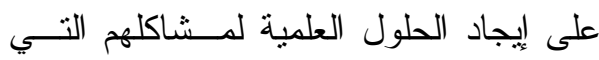
تمنل معوقات تمنعهم من ممارســة الحيــاة بشكل طبيعي في مجتمعهم، وكان من نتـائج

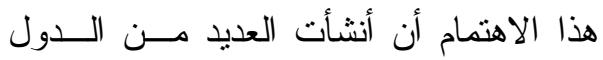
مؤسسات تعليمية ومر اكز بحثية تهتم بتعلــيم

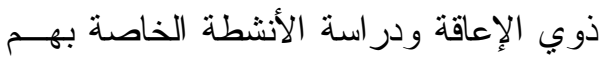


التربيـــة الخاصـــة وســبل مو اجهتهـــا

$$
\text { و التغلب عليها. }
$$

ب - كثرة المستفيدين من الارسة:

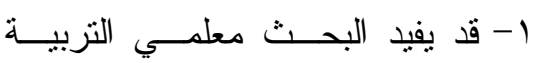

الخاصة في التعرف علــى أثــكال

و أساليب التتمية المهنية المنطورة.

ץ- يستفيد المجتمع من الطاقة البـشرية

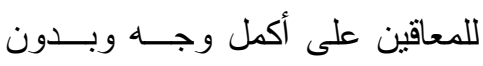

إهدار نتيجة لتحقيق النمو المتكامـلـل

$$
\text { للطالب المعاق. }
$$

ب- قد يفيد البحــث متخـــي القــرار

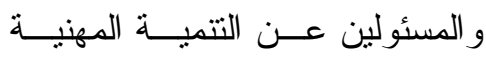

لمعلمي النزبية الخاصة.

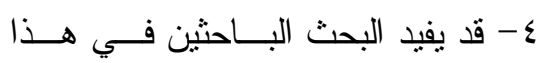

المجال لإجر اء أبحــاث ودر اســات

ذات علاقة بموضوع البحث.

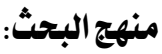

يستخدم البحــث الحــالي المــنهج

الوصفي لكونه من أنسب المناهج التي تهــنم

بوصف ما هو كائن وتفسيره ورصد الواقع، من خلد در اسة نظرية لتأصــيل المفــاهيم

العلمية لمتغير ات البحث.

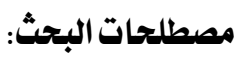

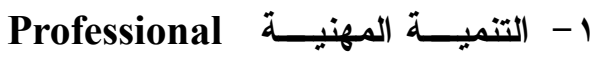

\section{Development}

نشاط مستمر بركز على المعلم من

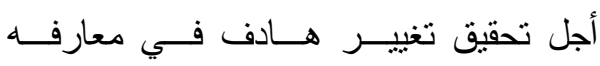

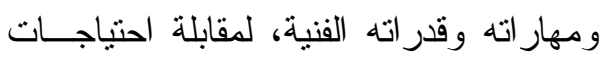

نظرًا لكونها دورات نقليدية نظرية تفنقر إلى

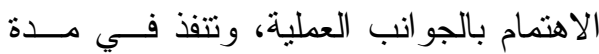

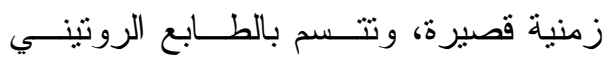

كجزء من متطلبات الالتحاق بالمهنة، وهو ما

أكدت عليه بعض الدر اسات مثــل دراســـة

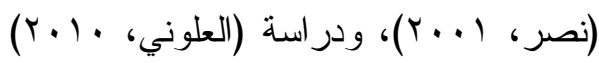

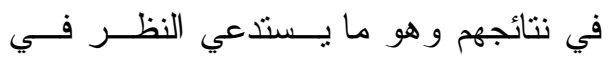

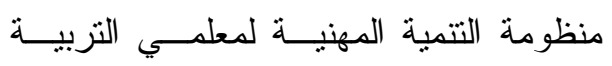
الخاصة و العمل على تطوير ها.

لذللك جاعت مشكلة البحــث الحــالي فــي

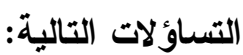

1- ما الإطار المفاهيمي للتنمية المهنية

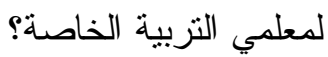

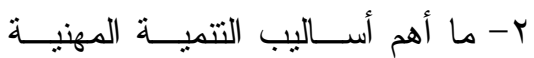

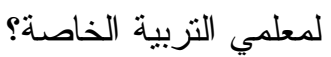

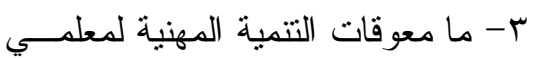
التزبية الخاصة؟ - اصن

ع - ما منطلبات التتمية المهنية لمعلمي

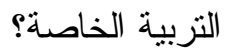

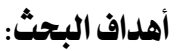

يهذف البحث الحــالي الكـشف عـن

معوقات التتمية المهنيـــة لمعلمــي التزبيــة الخاصة ومتطلبات مو اجهتها.

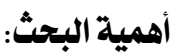
ترجع أهمية البحث الحالي إلى:

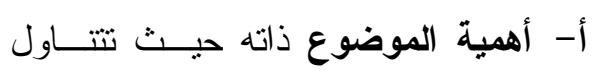

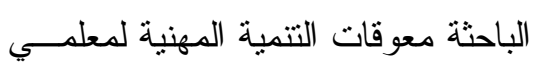


في بناء استبانة للتعرف على و اقــع التتميــة

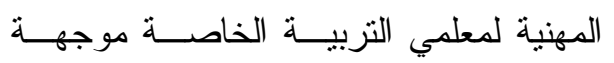

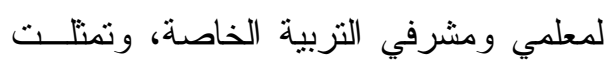

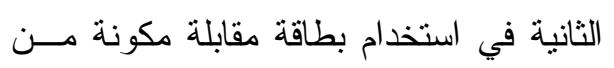

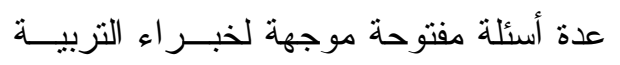

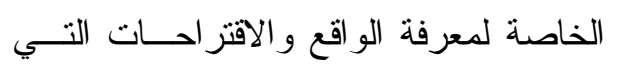

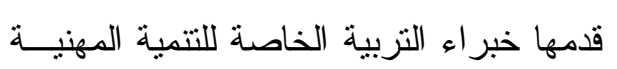
لمعلمي التربية الخاصة. وتوصلت الدر اسة إلى نتائج أهمها:

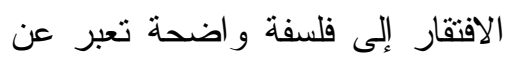

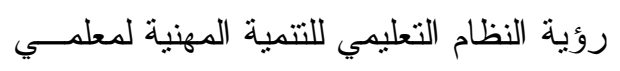
التزبية الخاصة، كما يعـاني واقـــع التتميـــة

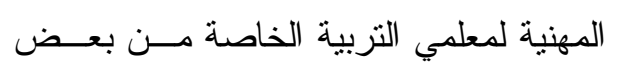

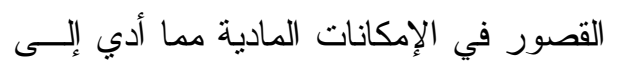

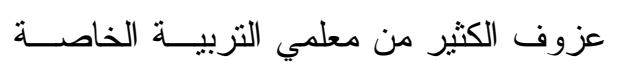

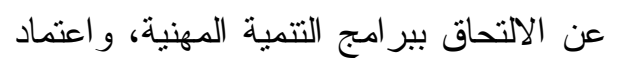

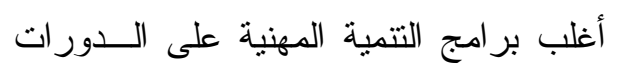
القصيرة، و عدم التوسع في بر امج الدر اسات العليا و الابتعاث وبر امج الزيار ات الدولية.

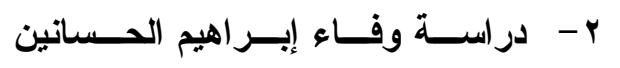

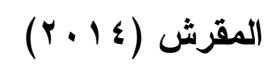

بعنوان: "تــصور مقتــرح للتنميــة

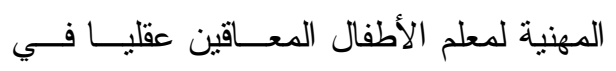
ضوء بعض الاتجاهات التربوية الحديثة" هدفت الاراسة إلى التعرف على أهم

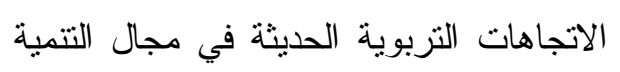
المهنية لمعلم الأطفال المعاقين عقليا.
محددة في الوضع الر اهن و المــستقبلي فـي

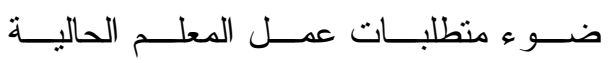
و المستقبلية، لتطوير أداءه داخل المؤسـسات

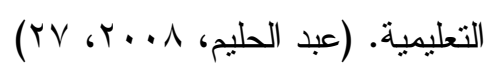

Teacher of معلم التربية الخاصـة Special Education

هو المعلم الــذي يقــوم بالتــدريس

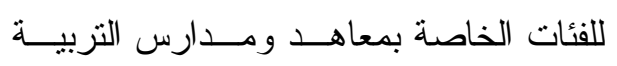

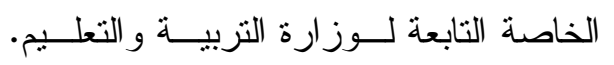

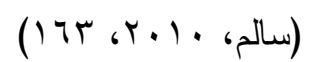
الدراسات السابقة: تشمل در اسات عربية وأجنبية سوف تعرضها الباحثة وفق التزتيب الزمنــي مـن درن

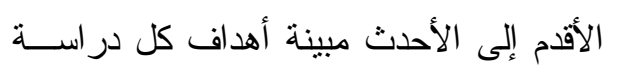
ومنهجيتها، وأبرز النتائج التي توصلت إليها. التها.

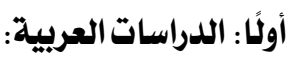
- - دراسة سالم محمــــ ســليم العلـــوني الدراسي $(r \cdot 1 \cdot)$

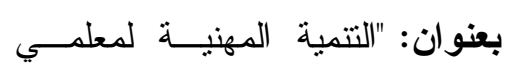

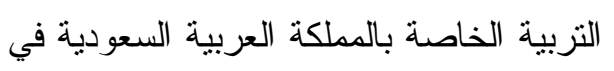
ضوء خبر ات بعض الدول"

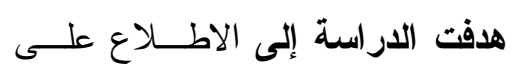
خبرات بعض الدول في مجال التتمية المهنية لمعلم التربية الخاصة ووضع تصور مقترح

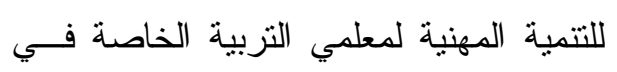
ضو ء خبرات هذه الدول. استخدمت الاراسة المنهج الوصفي،

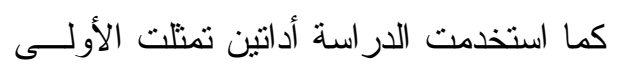


المهنية ومنخفـــي الكفــاءة المهنيـــة فــي

تو اصلهم مع الأطفال ذوي الإعاقـــة العقليـــة

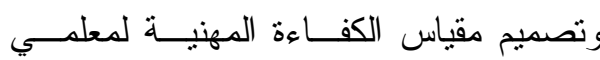
الأطفال ذوي الإعاقة العقلية.

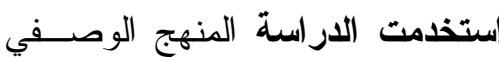

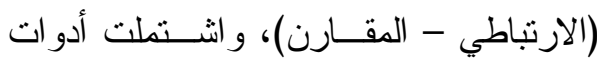

الار اسة على اختبار ستانفورد بينيه للـــكاء،

وقائمة الكفاءات المهنية لمعلمي الأطفال ذوي

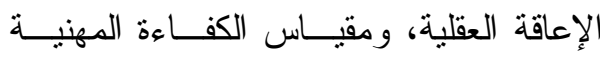

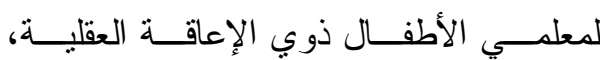

ومقياس التو اصل الثامل للأطفال.

وتوصلت الدراسة إلى نتائج أهمها:

وجود علاقة ارنباطية دالة موجبة بين

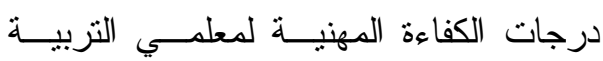

الخاصة ودرجات نو اصلهم مع الأطفال ذوي الإعاقة العقلية.

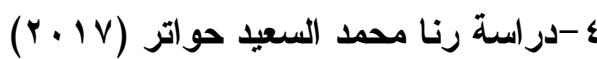

بعنوان: "متطلبات التتميــة المهنيــة

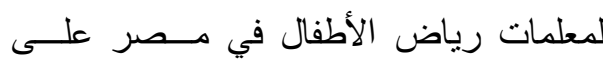
ضوء معايير الجودة والاعتماد"

هدفت الدراسة إلى تحديــد دو اعـي

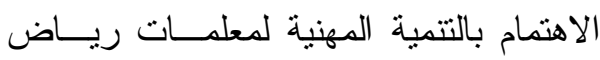

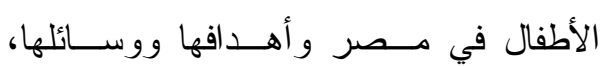

و الكثف عن و اقع التتمية المهنية لمعلمــات ولهات

رياض الأطفال في مصر وتحديد معوقاتهـا، ولكان

كما هدفت وضع تصور مقتــر ح لمنطلبــات التتمية المهنية لمعلمــات ريــاض الأطفــال
استخدمت الارسة المنهج الوصــي

التحليلي، وتكونت أداة الدراسة من اســنبانة

موجهة لمعلمي المعاقين عقليــا، و اســنبانة موجهة للخبر اء في مجال التربية الخاصة. وتوصلت الاراسة إلى نتائج أهمها: قصور فــي إعــداد معلــــم الأطفــال

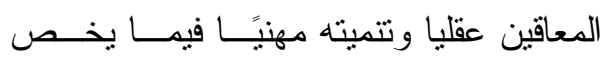

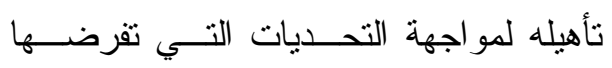

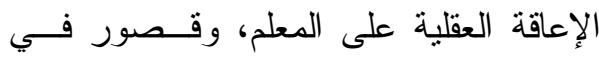

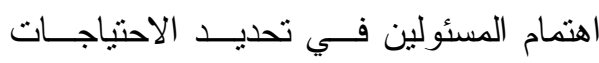

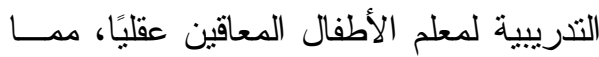

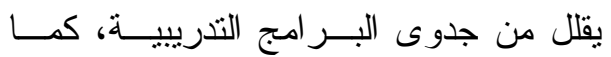
نوصلت الدراسة إلى عدم وجود تــشريعات

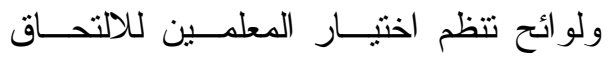

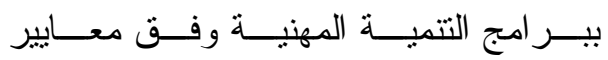
موضو عية تمنع تحيز المديرين عند ترشـيح المعلمين المتقدمين للتدريب. r - دراسة خديجة فتحي عبد الفتاح محمد

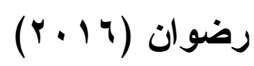

بعنوان: "العلاقة بين الكفاءة المهنية لمعلمي التزبية الخاصة ومهار ات التواصــل الكلي مع الأطفال ذوي الإعاقة العقلية"

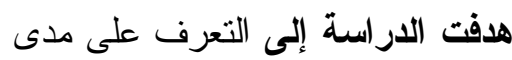

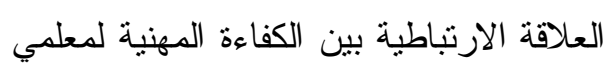

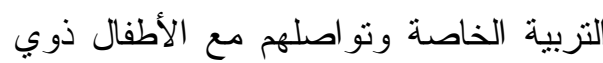
الإعاقة العقلية، و التعرف على الفروق بــين

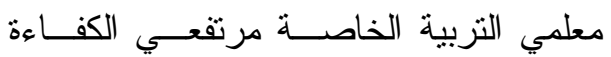


العالمي نحو الدمج، ووضع نصور مقتــرح

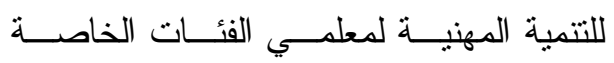

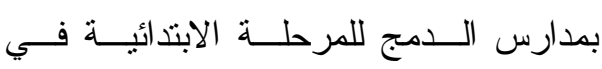

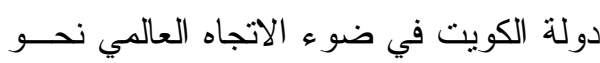

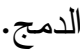

استخدمت الار اسة المنهج الوصــفي،

وتكونـــت أداة الدراســـة مـــن الاســنتبانة

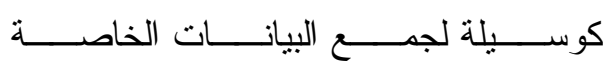

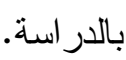

وتوصلت الدراسة إلى نتائج أهمها:

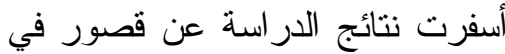

أهداف التتمية المهنية لمعلمي الفئات الخاصة بمدارس الدمج للمرحلة الابتدائية، وتعـددت لهات المعوقات التي تحول دون فاعليــة بـــرامج التنمية المهنية لمعلمـي الفئـات الخاصـــة بمدارس الدمج للمرحلة الابتدائية و التي تمنل أهمها في ضعف نظام متابعة أثز التـدريب، وقلة مشاركة المعلمين في تحديد احتياجـاتهم التدرييية، وأيـضـا قلــة نتــوع الأسـاليب المستخدمة فــي التــدريب، كمــا توصـلت الدر اسة إلى وضع العديد مــن المقترحسات الفاعلة لنطوير التنمية المهنية لمعلمي الفئات الخاصة بمدارس الدمج للمرحلـــة الابتدائيــــة

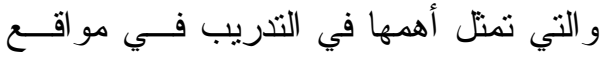
العمل بمدارس الدمج، و إنشاء أكاديمية مهنية

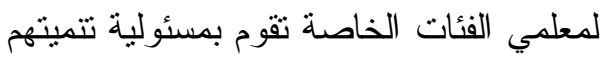
مهنيًا.
في مصر علــى ضــوء معــايير الجـودة

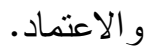

استخدمت الدراسة المنهج الوصــفي

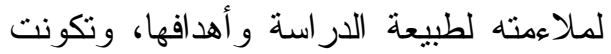

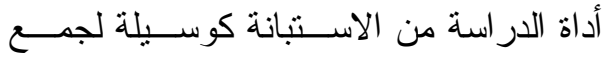
البيانات

\section{وتوصلت الدراسة إلى نتائج أهمها:}

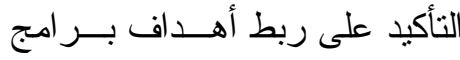

التتمية المهنية لمعلمــات ريــاض الأطفــال بالاحتياجــات الفعليـــة داخـــل الروضــــة، وضرورة وضع آليـات ومعــايير الجــودة الخاصة بالبر امج التذريبية من قبل الأكاديمية المهنية للمعلمين، و أيضا ضرورة الاســتفادة من خبــرات مبعوثــات ريــاض الأطفــال العائدات من الخارج و إسناد جانب من بر امج

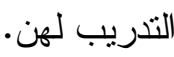
ه - در اسة شريفة جاسم (Y. IV)

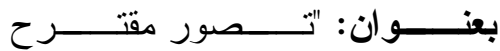

للتنمية المهنية لمعلمي الفئات الخاصة بدولــة الكويت في ضوء الاتجــاه العـالمي نحــو

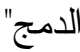

هدفت الاراسة إلى الوقوف على أهم

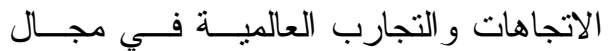
التتمية المهنية لمعلمـي الفئسـات الخاصــة،

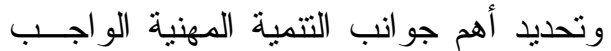
توفير ها للمعلمين بمدارس المدمج للمرحلـــة الابتدائية بدولة الكويت في ضـــوء الاتجــاه 
هدفت الاراسة إلى بحث تأثثر برنامج

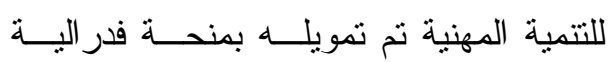

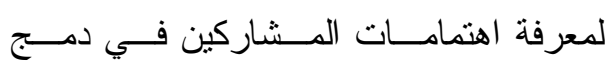

التكنولوجيا بالتندريس داخل المنهج ومعرفـــة الاختلافات في مستويات الاهتمام.

استخدمت الدراسة المنهج الوصــفي،

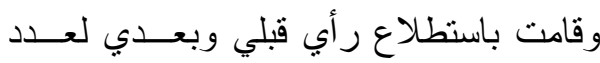

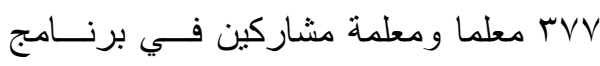

التتمية المهنية في البرنامج.

وتوصلت الدراسة إلى نتائج أهمها :

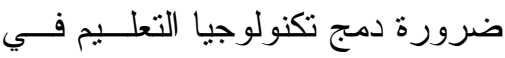

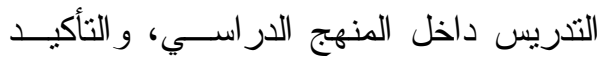

على أهمية تدريب المعلــم وتتميتــهـ مهنيًا

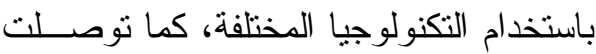

إلى عدم وجود فروق ذات دلالة إحصائية ما بين الجنس و المستوي الدراسي.

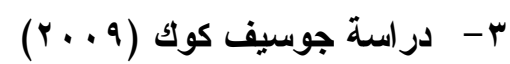

بعنـــوان: "دعــم التتميــة المهنيـــة

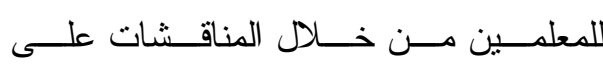
الإنترنت

هدفت الاراسة إلى استكثاف القيمـة

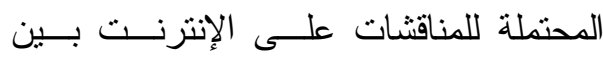

المعلمين كأداة للتتمية المهنية.

استخدمت الار اســـة مــنهج تحليـلـل

المحتوى، ونم تطبيق الدراسة على مجموعة من معلمي الرياضيات المخضرمين.

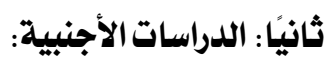

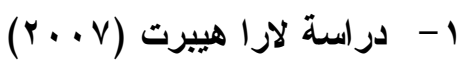

بعنوان: "تــصميم التتميــة المهنيــة

للمعلمين عن طريــق الــشبكة العنكبوتيـــة، النطبيق المرتبط بالنظرية"

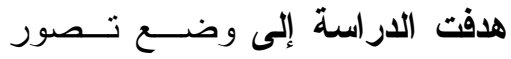

وأساليب مختلفة للتتمية المهنيــة باســتخدام الإنترنت وتقديم عدة نماذج تدرييية تـشجع بـاني على التعامل المشترك و التعاون بين المعلمين في مو اقع مختلفة.

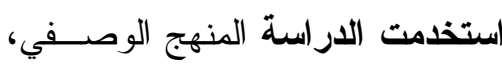

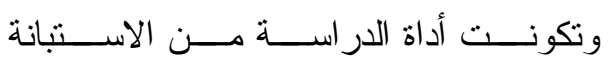
و المقابلات الثخصية المقننة. وتوصلت الدراسة إلى نتائج أهمها:

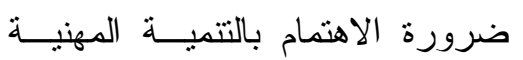

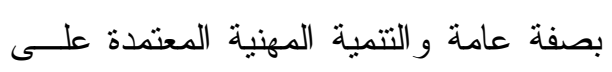
الثبكة العنكبونية، ووضهع تــصور مقتــرح للتتمية المهنية للمعلمين باســتخدام الـشبكة وفيكة

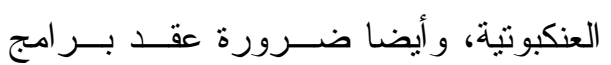

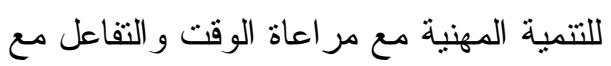
المعلمين والاتصـال و التو اصل المتبادل بــين المتدربين. r - دراسة ريتشارد أوفر باوق ورفليـنـج

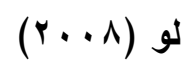
بعنوان: "تأثثير منحة ممولة فــدر اليا على بر امج التتمية المهنية للمعلمين و أهميــة

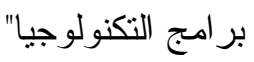


متطلبات التتمية المهنية ويشير ذلك إلـى أن

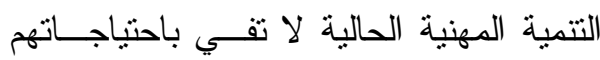
أنشئت للمعلمين على شبكة الإنترنت من أجل المهنية.

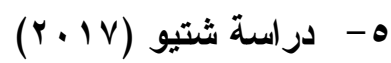

بعنــــوان: "الاحتياجـــات التدريييــة لمعلمي التزبية الخاصة في زمبابوي" بواني" هدفت الار اسة إلى تحديد الاحتياجات

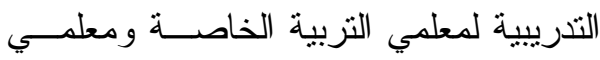

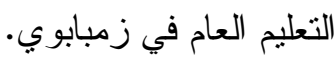

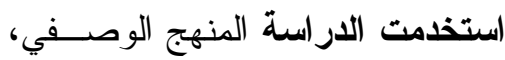

وقامت بتطبيق استبيان على معلمي المدارس تضمن أسئلة مفتوحة و أسئلة مغلقة. وتوصلت الدراسة إلى نتائج أهمها:

أعرب معلمــو المــــارس وخاصــــة معلمي التربية الخاصة عن حـاجتهم بــشكل كبير إلى تتميتهم مهنيًا في مجال عملهم، كما حدد المعلمون العديد من الموضوعات التـي اعتبرو ها مهمة لتدريبهم عليها.

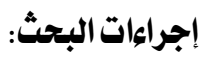

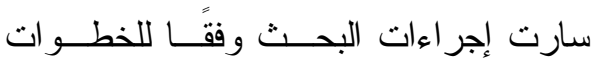

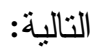

- الخطوة الأولى: الإطــــار العــام للبحـــث

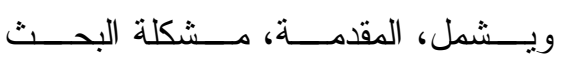

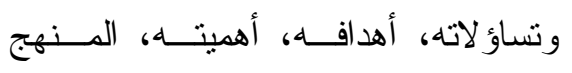
المستخدم، و الدر اسات السابقة.

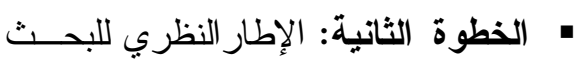

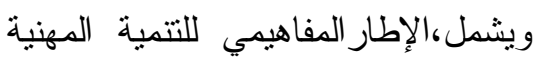

وتوصلت الاراسة إلى نتائج أهمها: وجود فاعلية فـي المنتـديات التـي لـــي

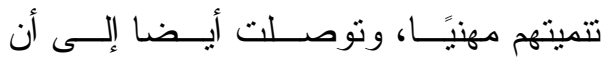

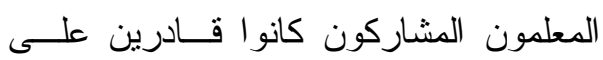
الربط بين النظرية و الممارسة عــن طريــق

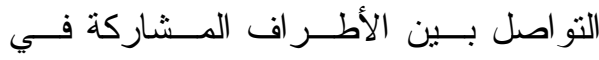
الدر اسة، وتم تفعيل قضايا خاصة بــالمعلمين عبر المناقثات على شبكة الإنترنت و التـي منلت دعمًا كبيرًا للتنمية المهنية. ع - دراسة أوجورمان (11) بعنوان: "التتمية المهنيـــة للمعلمــين العاملين في التربية الخاصة ومعلمي الــدمج في المدارس العادية" هدفت الدراسة إلى تحديد متطلبــات

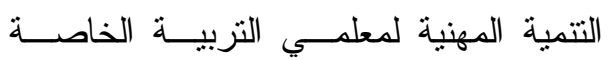
ومعلمي الدمج في المدارس العادية. استخدمت الاراسة المنهج الوصــفي، لوني،

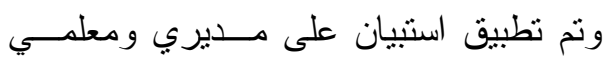
مدارس التعليم الأساسي في أيرلندا. وتوصلت الدراسة إلى نتائج أهمها:

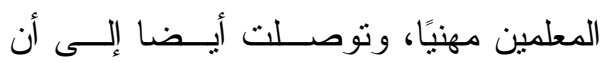
بر امج التتمية المهنية التي كانت أطول فــي المدة ومنتظمة ومنظمة ومدمجة كانت أكتثر فاعلية، وأيضا كان للمعلمين ذوي المؤهلات

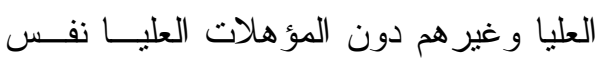
ضرورة مشاركة المدرسة في تتمية 
الزيادة، والتتمية تفيد حصول الفـرد علــى مزيد من الخبرات التي ترفع مــن كفاءتــهـ

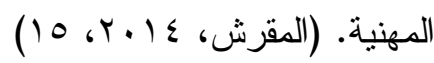

فيقــــد بالتتميــة Development

التحرر بالأمور من وضعها المبدئي البـسيط

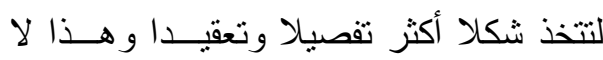
يتحقق إلا نتيجة لجهود يبذلها أناس عن وعي يبغون تحسين حياة مجتمعهم، فالتتمية تعنـي انبثاق ونمو كل الإمكانات و الطاقات الكامنة في كيان معين بشكل كامل ومنوازن، سواء كان هذا الكيان فردًا أو جماعة أو مجتمعسـا.

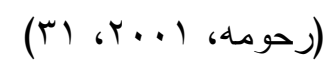

وتعددت تعريفــات التتميـــة المهنيــــة واختلفت باختلاف وجهات نظر الباحثين من

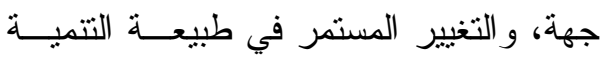
المهنية و أساليبها من جهة أخرى.

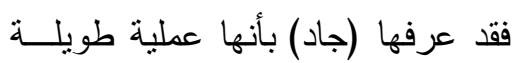
المدى، تبدأ منذ التخرج وحتى نهاية الخدمة، تتضافر فيها الجهود البـشرية والإككانــات

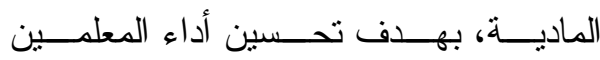
الممارسين داخل الفصول، وزيادة نموهم في الجو انب المعرفية و المهاريـــة والــسلوكية.

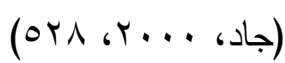

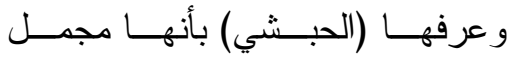

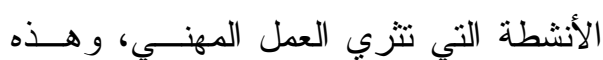
الأنشطة تشتمل على النمو الفردي، و التعلــيم المستمر و التذريب أثثاء الخدمة، بالإضـــافة
لمعلمي النزبية الخاصة،أساليب ووسائل التتمية المهنية لمعلمي التربية الخاصة، معوقات التتمية المهنية لمعلمي التربيــة

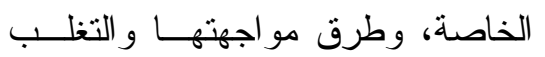
عليها.

\section{الإطار النظري للبحث}

في هذا القسم مــن البحــث تثتـــاول

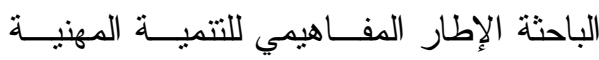
لمعلمي التربية الخاصة، و أساليب ووسـائل

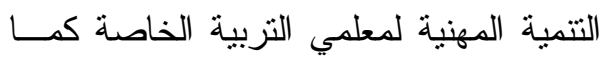
تتتاول معوقات التتمية المهنية لمعلمي التربية الخاصة، وسبل مو اجهتها و التغلب عليها.

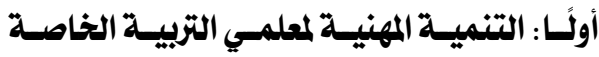

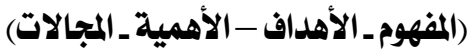
أ-مفهوم التنمية المهنية:

يثير مفهوم التتمية المهنية جدلًا كبيرًا في مجال العلوم التزبوية بهدف الوصول إلى مفيل

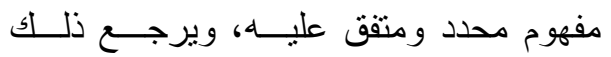
للطبيعة المتغيرة لعمليــة التتميــة المهنيــة، وبالتالي للتغير المستمر في أساليب توفيرها، ولمعرفة مفهوم التتمية المهنية ينبغي الإشارة

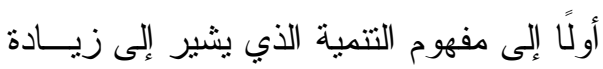

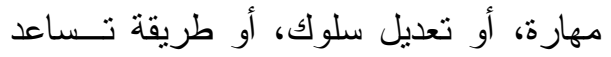

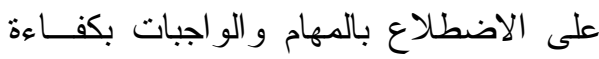

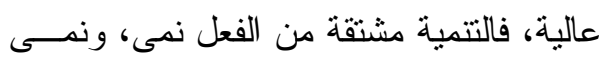

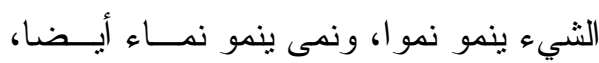

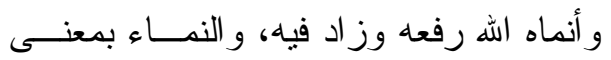


ويمكن تحديد أهداف التنمية المهنية لمعلمي

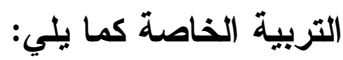

1- اطلاع المعلمـين علـى المـستجدات

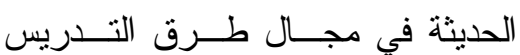
وتقنيات التدريس ومحتــوى المــنهزج

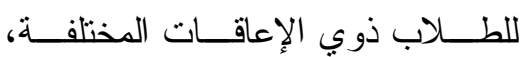

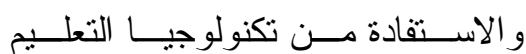
و التذريب الحديثة ونوظيفها في عملية

$$
\text { التدريس. }
$$

r- غرس روح الثقة بــالنفس و الارتقـــاء

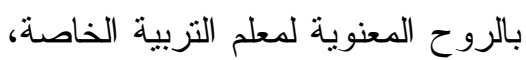
وتحسين الممارسات و الجودة و الأهداف

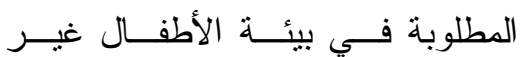
العاديين. ب- التعرف على التـشريعات و القــــوانين الخاصة بمجال التربية الخاصة. ع- التعرف على ضغوط العمل ومـشاكل

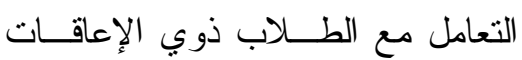

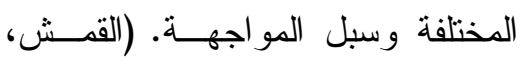

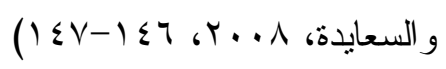
0- تعديل الممارسات المهنيــة للمعلمـين و المفاهيم الخاصة بالعاملين بالمدرسة.

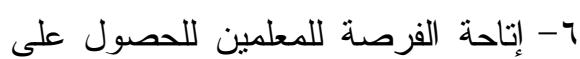

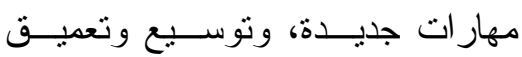
معرفتهم وفههم للأمور التربوية.
إلى تعاون الفريق، و الجماعـات الدر ســـية، وتدريب الفريق، وبمعنى أوسع كل خبـــرات

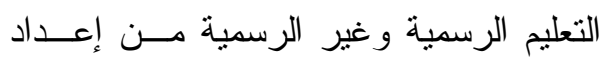
المعلم قبل الخدمة وحتى التعاقد، وفي زمسنـ

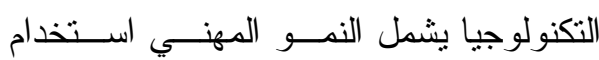

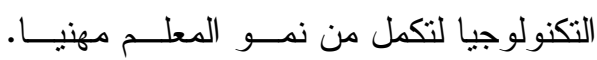

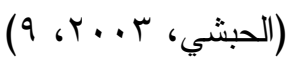
ويتضح من هذه التعريفات أن كافــة الآر اء تؤكد على ضرورة استمر ارية التتمية

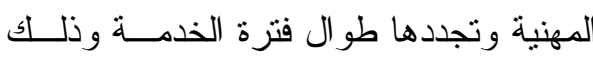
لمواجهة التحديات المتسار عة التي يتعـرض فوره

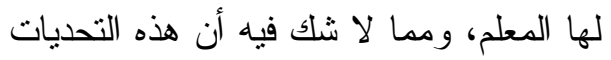

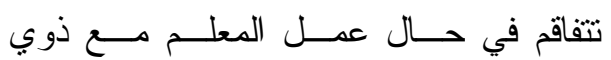
الاحتياجات الخاصة. ب-أهداف التنمية المهنية لمعلمي التربية

\section{الخاصة: - (الخاص}

تتبثق أهداف التتمية المهنية عادة من الفلسفة التي يتبناها النظام التذريبي في ضوء الفلسفة العامة للدولة، كما أنها تشتق من عدة لنتئن مصادر مختلفة، ويمكن القول بــأن التتميــة المهنية ليست مجرد نوفير خبر ات ومهار ات للأفر اد فقط بل أنها تتعدى إلى أبعد من ذلك، لتهرئ

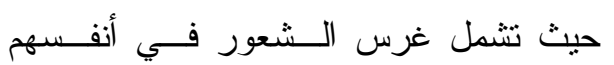
بالرغبة في تحسين قدر اتهم وتأهيل إمكاناتهم

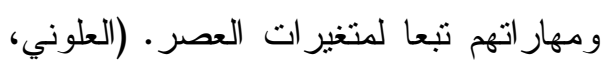




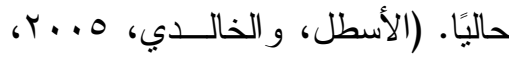

(rT⿱

rا-بعد استعر اض أهداف التتمية المهنية لمعلمي التزبية الخاصة نجد أن هدفها النهائي يتبلور في تحسـسين وتطــــير

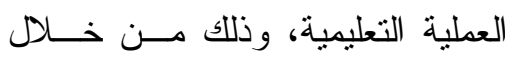
تزويد المعلمين بالأساليب الحديثة في مجال تربية وتعليم المعـاقين، وفـي بالي

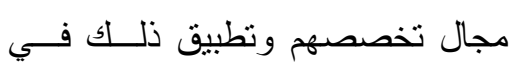
مدارس التربية الخاصة، وبالتالي رفع

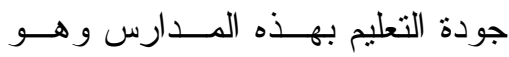
الهدف الأسمى للتتمية المهنية.

ج- أهمية التنمية المهنية لمعلمي التربيــة الخاصة ومبررات الحاجة إليها:

تحنل التتمية المهنية للمعلمين أهميــة

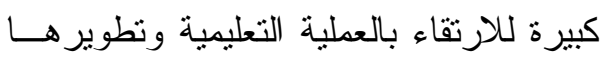

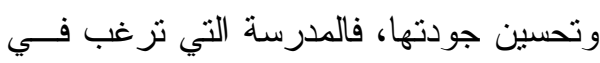
تحقيق التميز بصفة دائمة تعمل على تــــوفير

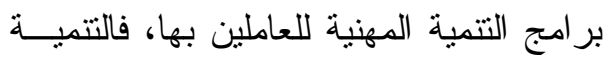

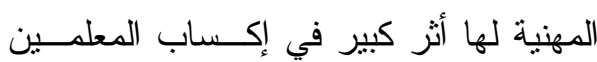
المعلومات و الخبــرات الجديــــة، وتحــــين

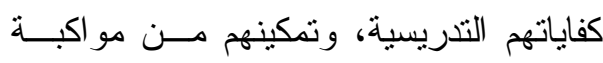

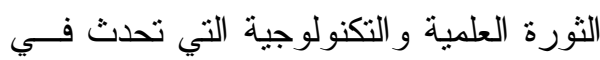
هذ العصر ، وتنساهم التتميــة المهنيــة فــي تدريب المعلمين على استخدام اســنز اتيجيات

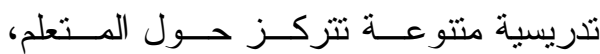

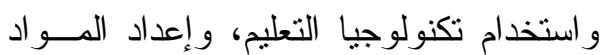

V- الرغبة في الترقي إلى درجة أو وظيفة

أعلى و الحصول على حوافز تشجيعية.

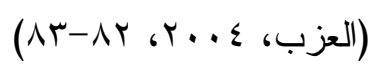

ᄉ- تلبية احتياجات معلمي التربية الخاصة

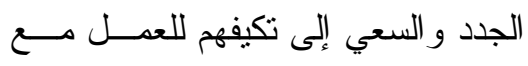

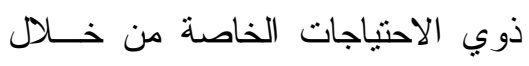

اكتسابهم الكثير من المهار ات المهنية.

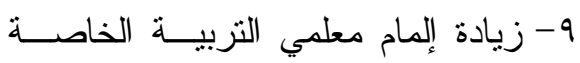

بالطرق، و الأساليب الحديثة في تعلــيم

ذوي الاحتياجات الخاصـــة، وتعزيــز فئس

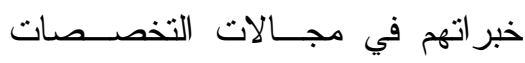

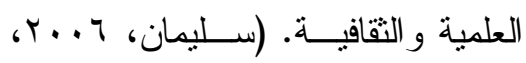

(1) 19

• 1-تتمية مهار ات معلم التربية الخاصـــة

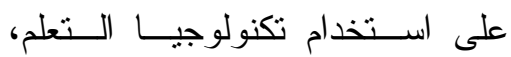

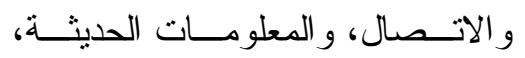

وتوظيفها في إثر اء بيئة التعلم داخــل

الفصل وخارجه. (الجمــال، ه...بك،

(rq)

11-علاج أوجه النقص و القـصور فـي

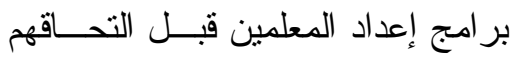
بالخدمة.

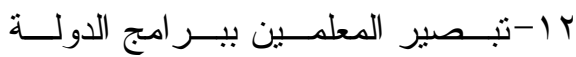
وخططها لتطوير التعليم، وتمكيــنهم من در اسة أهداف المجنمع ومشكلاته

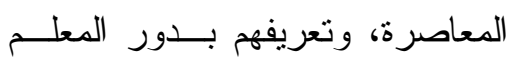


الجديدة و المتجددة لهم، وتتمية اســتعداداتهم

للاطلاع بهذه الأدوار، وتحمـلـ مسـسئوليات

إضـافية، ومعالجة جوانب القصور المختلفــة

لديهم، و الكثنف عن المــشكلات وضـــغ وط العمل المختلفة وسبل علاجهـــا، والاطــلاع ولع

على الاتجاهات الحديثة في مبـــدان التربيــة

الخاصة و الاستفادة منها.

وفيما يلي أهم المبررات التي دعــت

إلى ضرورة الاهنمام بالتتمية المهنية لمعلمي

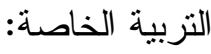

1 - مبررات معرفية: مسـن حبــث التقــدم

العلمي الكبير في جميع المبادين وتقدم وسائل المعرفة وتطور مفهوم العمــل حيث يستلزم تعليم المعلم تعليمًا مستمرًا

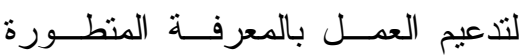

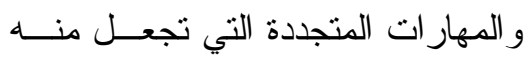
قوة فعالة في إحـــداث تغييــر أفــضـل

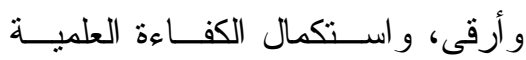
و المهنية مــن خــلال لـ إعــادة تأهيـلـل وتدريب المعلمين لمو اكبة التقدم العلمي و التكنولوجي الــذي بـسير بـسر عة متز ايدة مما يؤكد اســتمر ارية التعلـــيم للمعلم لتتمية طاقاته الذاتية. (المهــدي،

(rVT G r.)

r - مبررات تكنولوجية: حيث إن المعلـــ في حاجة إلى معرفة استخدام الآليــات الحديثة كالحاســب الآلـــي وشــبكات

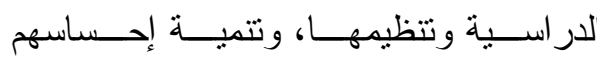

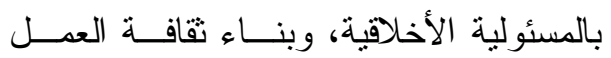
الجماعي، فالتنمية المهنية هي الأسـاس لبنــاء ثقافة الجودة و الإتقان و التميز فـــي التعلـــيم،

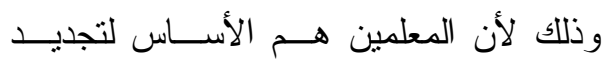
العملية التعليميــة وتطوير هـــا وتحــسينها. (حسن، 1 ( 1 . و لأهمية التتمية المهنية للمعلمين قامت كثير من الدول المتقدمة بإنــشاء مؤسـسـات متخصصة في التتمية المهنية أثتاء الخدمــة تقوم على تتبع خريجـي كليـات المعلمـين وكليات التزبية وتطـــوير أدائهــم وتحــسين نمو هم المهني، كما قامت بعــض الكليــات بدعوة خريجيها على فنز ات متفاوتة لمناقشة مشكلاتهم التدريسية وتحليلها وتقديم العــون و المشورة لكافة المعلمــين أثثــــاء الخدمـــة.

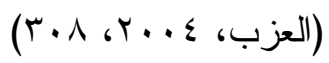
و إذا كانت التتمية المهنية للمعلم بصفة عامة لها أهمية كبرى فإن التتميــة المهنيــة

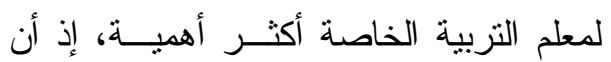
هؤ لاء الأطفال بمختلف فئاتهم لديهم مشكلات كثيرة ومتتو عة، هذه المشكلات تسنلزم مــن

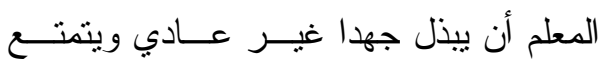
بصفات شخصية ومهنية تساعده على النجاح

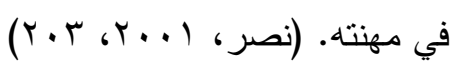
ومن ثم تتضح أهمية التتمية المهنيــة لمعلمي التربية الخاصـــة، لمواجهــة الأدوار 
الحاكمة لعمليات التتميــة الاقتــصادية

و الاجتماعية والتي جعلت المجتمعـات

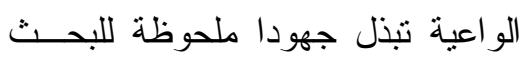

عن طاقات جديدة من المعلمين تسنطيع

أن تقوم بدور ها في تتمية الوعي بأبعاد

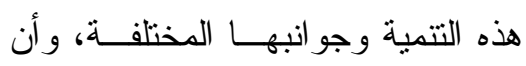

تتفادى المشكلات و التي من أهمها:

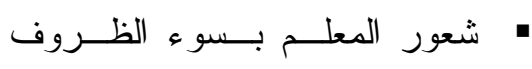

الاقتصادية التي يعمل فيهــا مـنـ

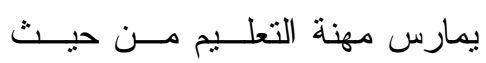

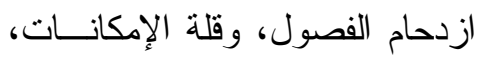

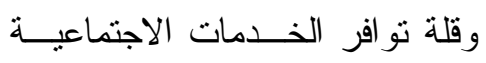

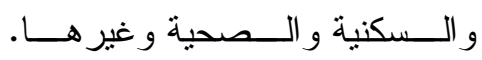

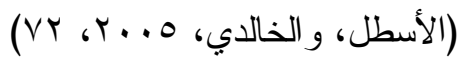

• الانخفاض الو اضتح لــدى المقبلـين

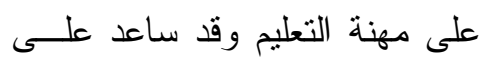

تفاقم هذه المشكلة النظرة التقليديـــة

التي ينظر بها أفراد المجتمع للمعلم

و التي انعكست بالضرورة مع تدني

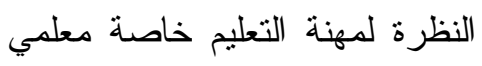

الأطفال ذوي الاحتياجات الخاصة.

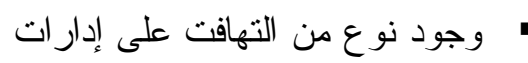

الإعارات مــن القـائمين بمهنـــة

التعليم، ويؤدي هذا الأمر إلى افتقاد

الدول التي يهاجر أبناؤها للعناصر

القادرة على تحقيق التتمية البشرية
الوســائط المتعــددة و آليــات البحـــث

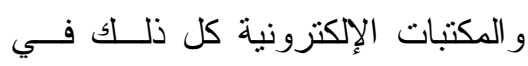

حاجة إلى نتمية مهنية للمعلمين لسهولة

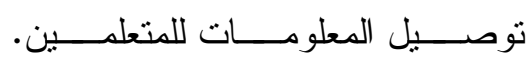

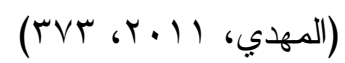

r- مبررات تربوية: حيث إن ما يستحدث

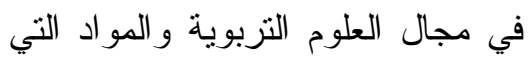

يتخصص المعلم في تدريـسـها يثيــر

العديد من التساؤلات حول دور المعلم

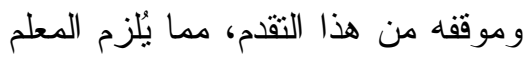

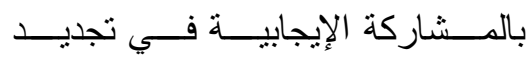

معلو ماته وتحسين مهار اته.

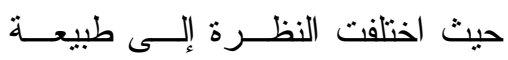

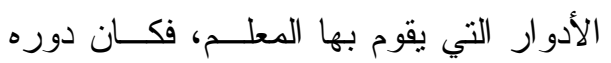

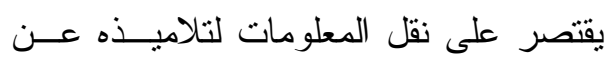

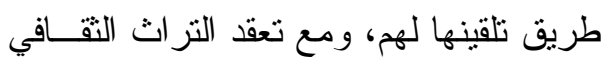

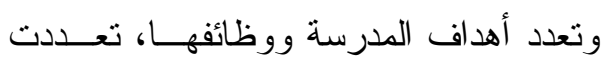

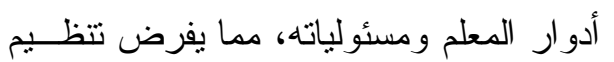

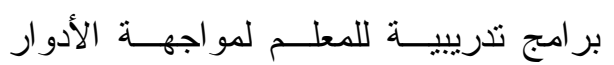

و الوظائف المختلفة التي يفرضــــــا اســـتخدام

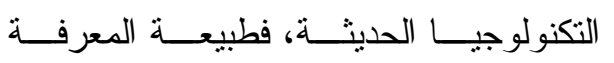

و الاكتشافات العلمية قد عدلت في مهام المعلم

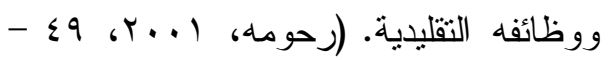

(o.

ع - مبررات اجتماعية واقتصادية: حيـــ

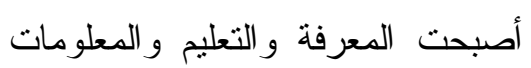

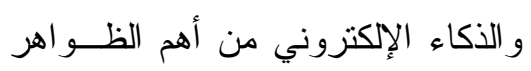


فهم طلابهم ومطالب نمو هم في كل مرحلـــة

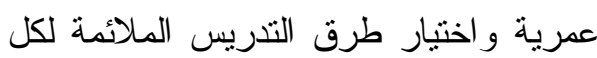
مرحلة.

ومن ناحية أخــرى بـسهرم المجــال

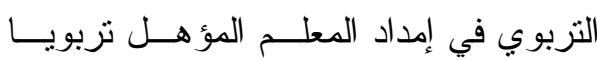
بالجديد في الثقافة النفسية و التربوية، وطر ائق التدريس، و المناهج ونظريات النمو و التعلم، وخاصة بعد ظهور استر اتيجيات ونظريـات

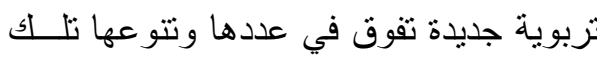

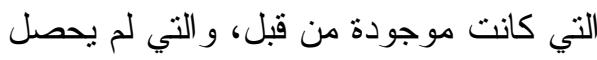

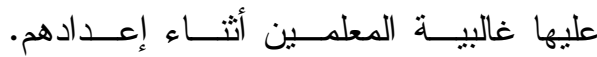

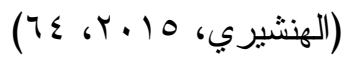
r- المجال الأكاديمي التخصصي: تتز ايد المعلومات الأكاديمية وتتطور الاديمي باستمر ار ومن ثم وجــب علــى المعلـــم أن

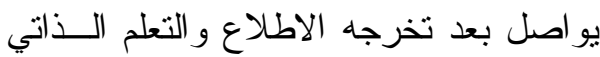
المستمر حتى يمكنه أن يقدم لتلاميــذه مـــادة علمية منطورة ومتجددة، وصـــلاح التعلــيم يأتي من صلاح المعلم ذاتـــهـ أولا، فالتتميــة المهنية تبدأ من تتمية المعلم لذاته. (رحومه،

$$
(\leqslant r, r \ldots)
$$

ويقوم المجــال الأكــاديمي للتتميــة

المهنية بإمداد المعلم بالأسلوب الذي يمكنــهـ

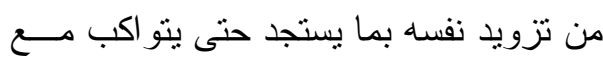

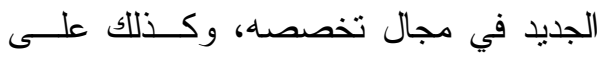

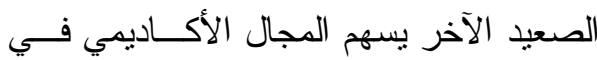

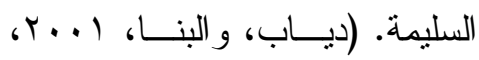

$(\wedge \wedge$

د -مجالات التنمية المهنية لمعلمي التربيــة

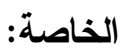

يجب أن تتاح لمعلم التربية الخاصــة

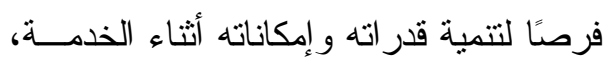
ورفع مستو اه الأكاديمي و المهنــي و الثقــافي

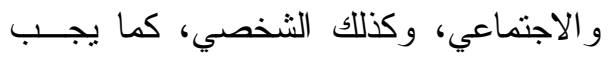
تتمية مهار اته الإدارية و الفنية للقيام بالأدوار و المسئوليات المتوقعة منه، ولذلك فإن للتنمية المهنية مجالات متعددة نتتوع بتتوع جو انب

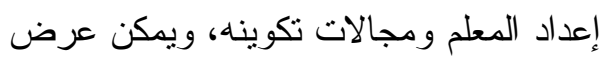
هذه المجالات على النحو الآتي: 1- المجال التربوي المهني: نتيجة للتوسع في التعليم كانت هنــاك

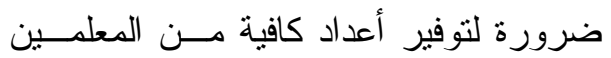

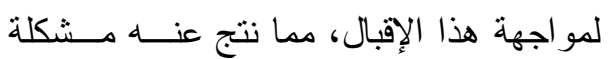
معلم الضرورة الذي لا تؤهله ثقافته و إعداده

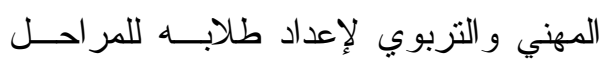

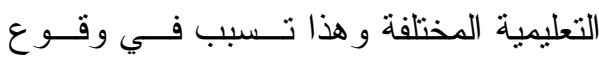

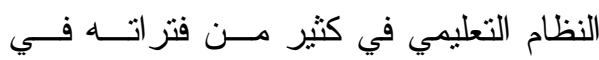

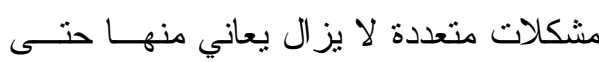

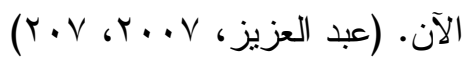

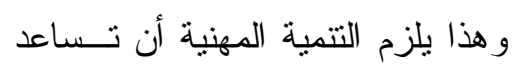

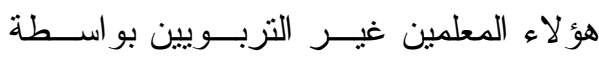
بر امجها التربوية و النفـسية فــي نوصــيل المعلومات للطلاب من خلال توضيح كيفيـة 
و التّريس منل المظهر ، و القيم و الاتجاهــات، و الأخلاق المتصلة بمهنة التعليم و التي نتكل ولني ولتهل في مجموعها سمة الالتز ام بالمهنة و الانتماء

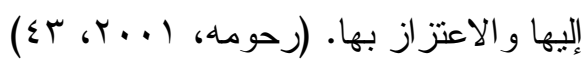
ه- - المجال الإداري:

يعتبر المجال الإداري أحد المجالات التي تسهم في تتمية المعلم وتجعله قادر ا على لئى

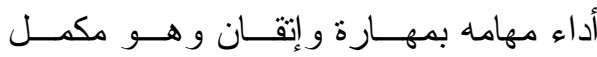
للمجالات الأخرى ويجمع بينها في تتاسق من أجل تكامل شخصية المعلم التعليمية الذي يعد أهم الأركان الأساسية في العملية التعليميــة

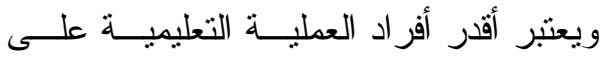

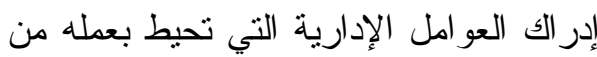

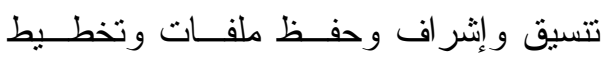

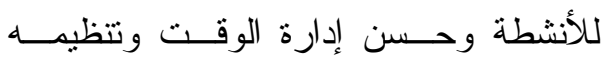
و التعاون لتكوين الصلات الإنسانية الحميمــة وتئة بينه وبين الطلاب وكذلك المعلمين بحيث تتم عن روح المودة والــصداقة، وهـــذا يمكـن ونـن المعلم من السيطرة على مجريــات الأمــور

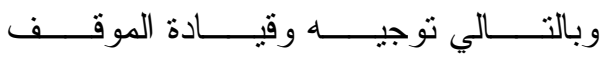

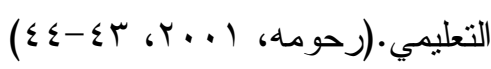

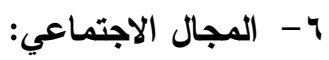
بركز المجـــال الاجتمـــاعي للتنميـــة المهنية للمعلم على غرس المهارات، و القـيم

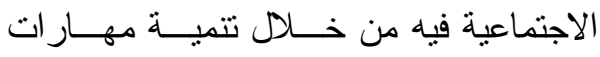

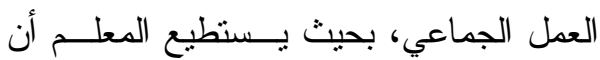

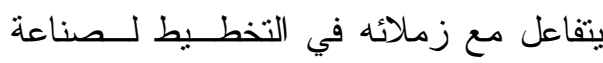

علاج بعض أوجه القـصور فــي الإعــداد

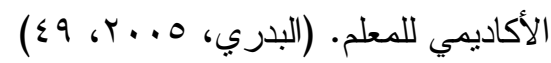

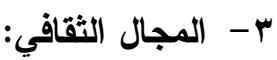

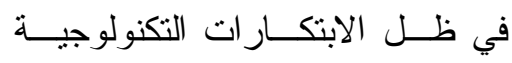
و التز اكم المعرفي في عالم ســريع التغيــر ،

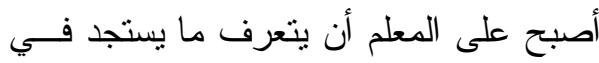

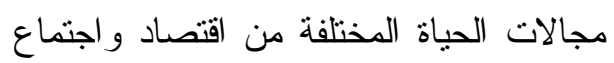
وسياسة وثقافة عامة، وكل ماله صلة بتطوير

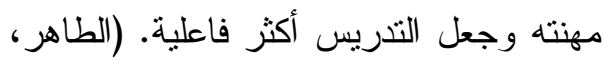

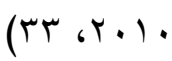
وتشير بعض المؤتمرات التربوية إلى

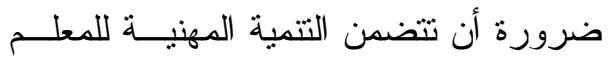

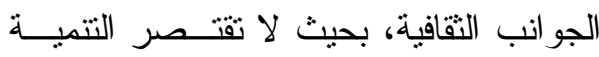

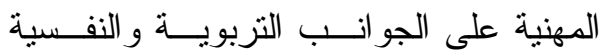

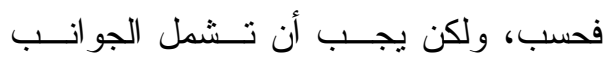
الثقافية، فيكون هناك اهتمام بالموضــوعات

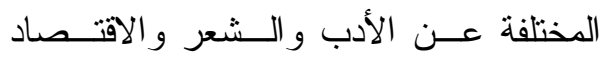
و السياسة وهكذا؛ لأن ثقافة المعلم هي إحدى ولى

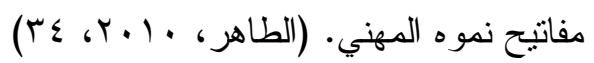
ـ - المجال الثخصي: يؤثز المعلم بـسلوكه فــي أوســاط

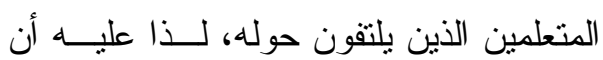

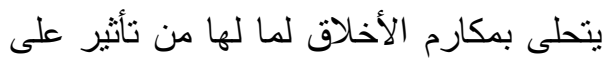

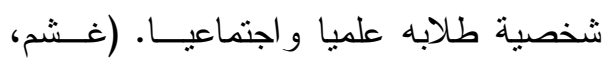
(9. 6. T.V

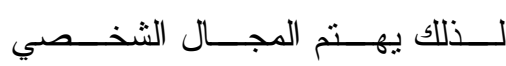
بخصائص المعلمين الإنسانية البناءة للتعلــيم 
للقائمين بعملية التعليم في كافــة الدـستويات

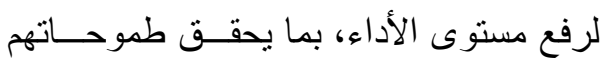
و استقر ارهم النفسي ورضاهم المهني تجــاه عملهم وإخلاصهم في أدائه، فبدون التدريب

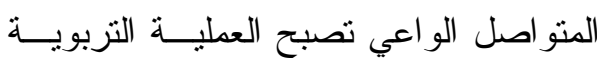
نمطية وعقيمة؛ حيث إن المطالب النزبويـــة ومجابهة التحديات التقنية الجديــدة ســنكون معتمدة بشكل كبير على بر امج التدريب أنثاء

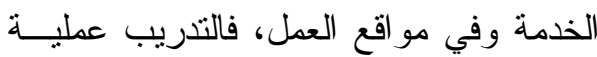

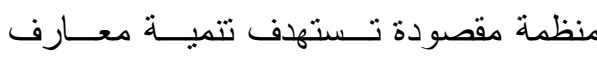
المعلم ومهار اته المهنية و إكسابه الاتجاهــات المناسبة لتمكينه من أداء وظيفته بكفاءة، وهو

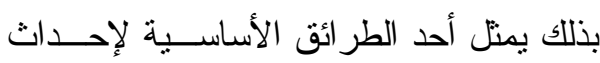

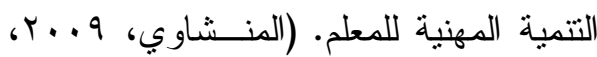
$(I V \cdot r$ وتتمثل أهم الأساليب التدريبية فيما يلي: • المحاضرة Lecture. • حلقات المناقتشة Discussions. "ورش العمل Work Shop. • در اسة الحالة Case Study. • تمثنيل الأدوار Role Playing. • العصف الذهني Brain Storming. • التدريب المصغر Micro Training.

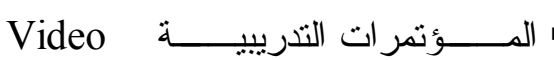
Conference

$$
\text { (70-0) }
$$

القرارات على مستوى المدرســة، وكــذللك لتمكين المعلم من التعامل بروح الفريق مـــع زملائه وطلابه، و غرس قيم التعليم التعاوني بين طلابه. (Dufour, 2000, 15) وتأسيسا على ما سبق ترى الباحثـــة أنه يجب إعطاء الجوانـب الـسابقة أهميــة خاصة في التتمية المهنية لمعلمــي التزبيـــة الخاصة، وأن يتم تتاولها بشكل أكثر شمولية عن ذي قبل؛ لأن المعلم هو محور التعلــيم ورعايته تعد مسئولية قومية يجب أن بيضافر الجميع لإنجاز ها.

ثانيــا : أسـاليب التنميـة المهنيـة لمعلمـي التربيـة

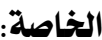

تتعدد تـصنيفات و أســاليب التتميــة المهنية للمعلمين وتتتوع لتو اكب التغيــرات و التطورات التي تحدث في المجال التزبوي، وإن كانت جميعها تدور حول فكرة واحسدة وهي أن يتحول المعلمون إلى متعلمين دائمي

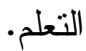
ومن أهم الأساليب التي يمكن الاعتماد

عليها في تتمية معلمي التربية الخاصة مهنيًا ما يلي:

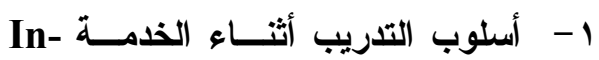
Service Training

يعد التدريب أثناء الخدمة مـن أهـــ

أساليب التتمية المهنية في عالمنا المعاصــر؛ حيث بستهدف أساسا تحقيق التتمية المهنيــة 
المقابلات ينتج عنها بناء مستويات مرتفعــة

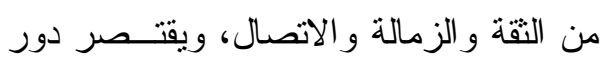
المشرف أو المدير على التوجيــه و الـــــم.

(Villegas-Reimers, 2003, 97-99) ويتفرع من هذا الأسلوب عدة أساليب

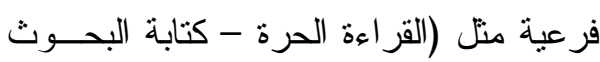

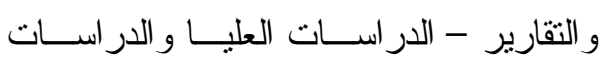
التكميلية - وسائل الإعلام المختلفة - التعلم

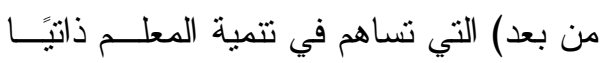

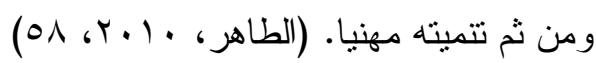

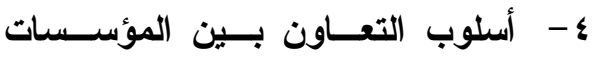

\section{المختلفـــ Inter- Institutional}

\section{Collaboration}

يتضمن هذا الأسلوب التعـاون بـين

المؤسسات التعليمية المختلفة المهتمة بقضايا التعليم، وقد يتخذ صور ا متعددة منها: • الثر اكة بــين المــــارس و الجامعــات، ووزارة التزبية و التعليم، ويكون الههف

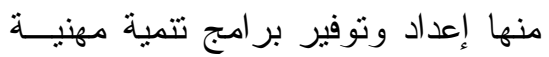
مستمرة للمعلمين في مجـالات محــددة

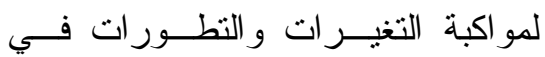

$$
\text { المناهج. }
$$

• الثر اكة بــين المــــارس و الجامعــات، ومؤسسات المجنمع المختلفة (الاقتصادية - الاجتماعية - التجارية - الــصناعية) وتهدف إلى تعــرف الطالــب المعلــــ للمهار ات المطلوبة في تلكك المؤسـسات ristance - أسلوب التعليم عن بعــ

\section{Education}

يهنم هذا الأسلوب بمساعدة المعلمــين على الحصول على المعرفة و العلم و التدريب

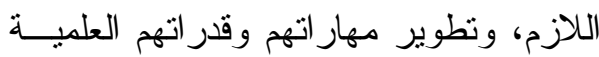
و العملية في مختلف التخصصات عن طريق

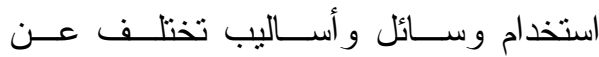
الأساليب المستخدمة في نظم التعليم العادية، ولقد أطلقت عدة تسميات على التعليم عن بعد لطدي

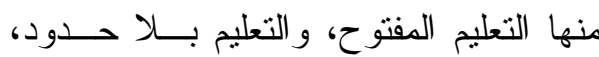
و التعليم بالمر اسلة، ويستخدم هذا الأسـلـوب لهاب

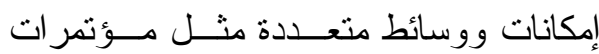
الفــــيو كــــنفر انس، و البـــر امج الإذاعبـــة

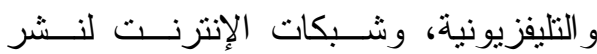
المعرفة المهنية المستقاة من بحــوث الفعـل المنل التي تجريها بعض المدارس من أجل تبــادل

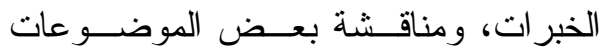
الخاصة بالنمو المهني وتطـــوير المــــارس.

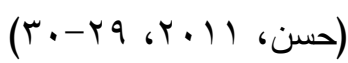

Self- أسلوب التنمية المهنية الذاتية،

\section{Development}

يقوم المعلمون فـي هــذا الأسـلوب بتحديد هدف معين ثم يعملون عالـى رصـــ الأنشطة و الموارد المطلوبة لتحقيقه ويعدون طرق التقويم المناسبة، ولضمان فاعلية هـــا الأسلوب يلزم وجود تغذية مرتدة موضوعية،

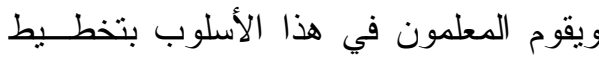

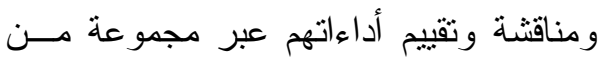


ومحاولة التعديل إلى الأفضل، ويساعد هـــا

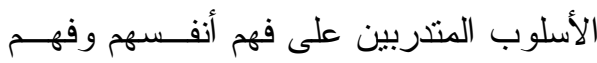

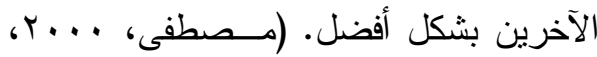

(rAY-YA)

- أسلوب التدريب علــى رأس العــل School Based Training

يقوم هذا الأسلوب على فكرة أن تكون

المدرسة المكان الذي يتت فيه التتمية المهنيـــة

للمعلم، حيث تكون فيه الدافعية الذاتية للمعلم منوفرة بصورة أكبر، وأن يمارس المعلمون

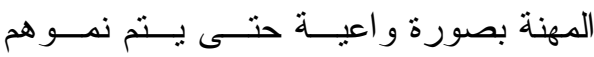

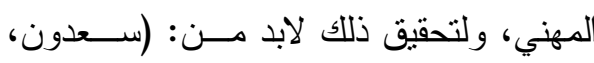

$$
\text { (V. - -79، r. T) }
$$

- تو اصل المعلمين سويا، ويتحدثون حول ممارساتهم المهنية لإيجاد لغـــة مهنيــة

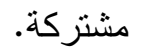

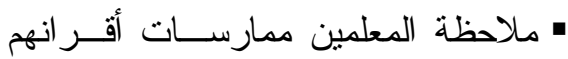

المهنية، وأن يـستقفيدو ا مــن التغذيــة

$$
\text { الر اجعة فيما بينهم ولهن }
$$

$$
\text { • مشاركة المعلمين فــي إعــداد المــواد }
$$

التدريسية، وتخطيطها وتقويمها.

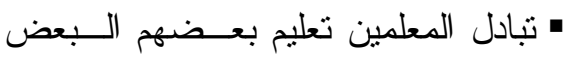

$$
\text { فنيات ومهار ات التدريس. }
$$

ورغم تعدد الأساليب المستخدمة فـي

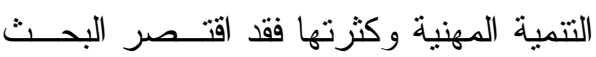

الحالي على عرض أهم الأساليب التي يمكن

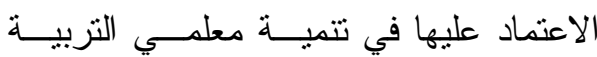

فيعملون على تتميتها في طلابهر عنــد

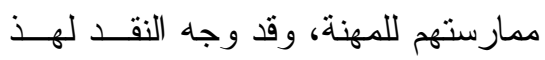

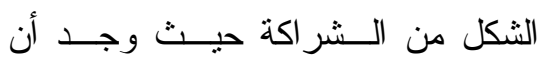

الطلاب المعلمين لم يتمكنوا من تطبيــق من فئن

ما اكتسبوه من خبــرات. (- Villegas-

(Reimers, 2003, 78-79

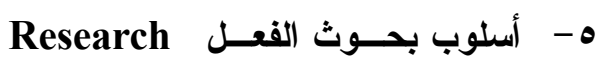

\section{Function}

يعد هذا الأسلوب من الأساليب الفعالة

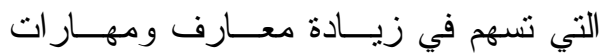

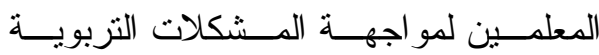

و التغلب عليها، وتتمية قدرتهم على التفكيــر

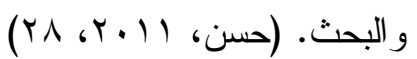

وفي هذا الأسلوب يكلف المت بـدربون

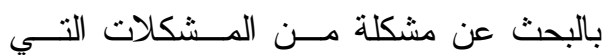

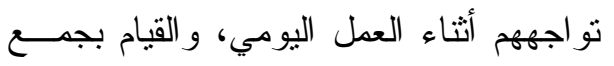

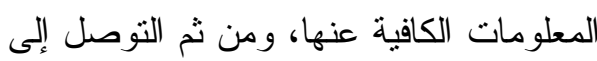
بعض المقترحات و التوصيات التي تؤدي إلى لى لـ إنى

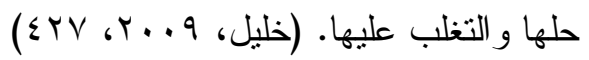

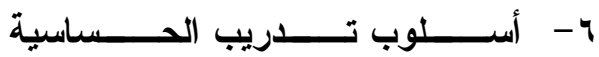

\section{Sensitivity Training}

يستخدم هذا الأسلوب لتتمية المهارات السلوكية لدى المتدربين، ويتم التدريب تحت

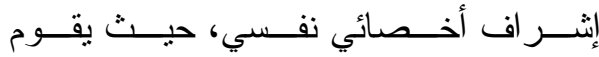
المتدربون بمصارحة بعضهم وطرح آرائهم في سلوك كل منهم تجاه الآخر مع مر اعـاة الصر احة، ويهدف هذا النوع من التـدريب إلى وعي المتدرب بحقيقة سلوكه وتــــرفه 
• عزوف المعلمين عن بــر امج التتميــة

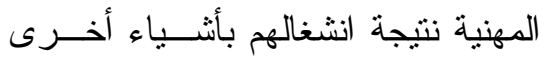
و عدم مناسبة توقيتها.

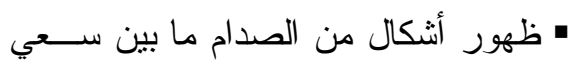

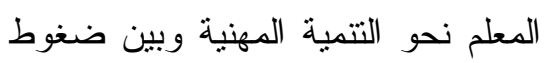
الإدارة المدرسية التي تعجز عن تـــوفير البديل وتعجـز عـن تعـديل جــدول الحصص الأسبوعي بما يسمح بإمكانية

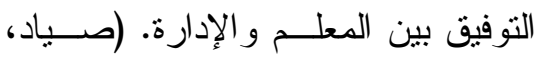

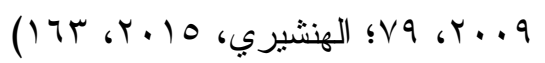

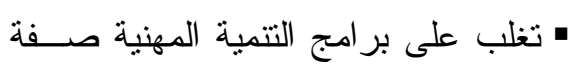

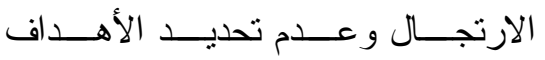
و الاحتياجات التدرييية اللازمة. - قلة وجود لجان مختصة لتخطيط برامج التتمية المهنية وتحديد أسلوب التـدريب في كل برنامج. - غياب استر انتيجية و اضحة المعالم لأسس برس

$$
\text { اختيار المعلم المتدرب. }
$$

- ضعف المحاسبية ونظم التمويل المخطط و المدروس في برامج التتمية المهنيــة.

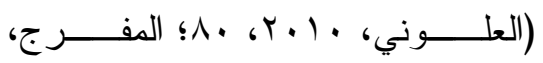

$$
\text { (rq } r \text {. . . V }
$$

ب- معوقِــات تتعلــق بــنقص الإمكانـــات

$$
\text { البشرية: }
$$

• ضعف الإقبال من المتدربين على برامج

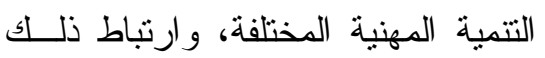

$$
\text { بقلة الحو افز المالية و الأدبية. }
$$

الخاصة، ومما لا شك فيه أن لكل أسلوب من الأساليب السابقة مميز ات و عيـــوب مختلفـــة عن بعضها، ولكل أسلوب وقته وزمانه الذي وني

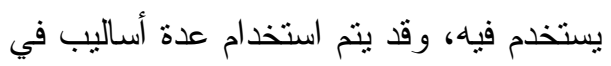

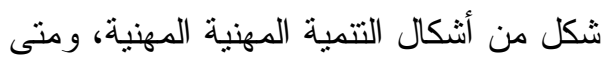
ما تم استخدام الأسلوب الأمثل فــإن عمليـــة التتمية المهنية نسير بالصورة المناسبة وتثقدم بالشكل المطلوب. - مبله

\section{ثالثا: معوقـات التنميـة المهنيـة لمعلمي التربيـة}

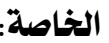

على الرغم من تز ايد الاهتمام بقضية

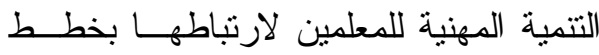
وبر امج إصلاح التعليم فـي مــصر ، إلا أن هنالك بعض المعوقات و المشكلات التي تعوق

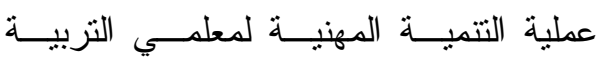
الخاصة، و التي يمكن رصدها كما يلي:

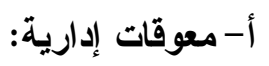
• صعوبة تفرغ المعلمين لحضور بـــر امج الدرائ التتمية المهنية أثثاء العام الدراسي. لتعين

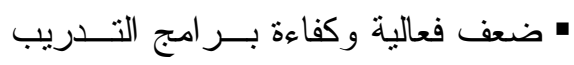

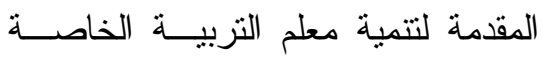
مهنيًا. • نقص التوثيق و المعلوماتية عن بـر امج

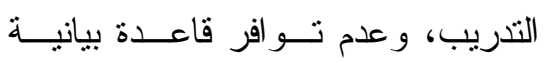

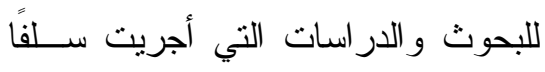
وبالتالي تصطدم البرامج الجديدة للتنمية المهنية بالفشل. 


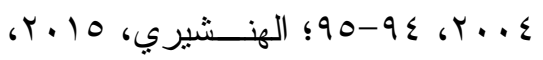

(1)

د-معوقات تتعلق بمحتوى البرامج:

• اقتصـار محتوى برامج التتمية المهنيــة على الجوانب النظرية فقط وعدم إثباع حاجات المعلمين. • عدم مسايرة بعض البرامج للتطـــــات العلمية و التزبوية الحديثة. • عدم التتاسب بــين محتــوى البرنــامج التدريبي و الوقت الذي يتم فيه البرنامج. • عدم وضوح الهدف من بر امج التتميــة المهنية بالنسبة للمتدربين. • تقليدية بر امج التتمية المهنية و افتقار هــــا للحداثة. • اعتماد أغلب برامج التتمية المهنية على الدور ات القــيرة. (صــياد، 9 . . ب،

$$
\text { (r纟. }
$$

ه-معوقات تتعلق بالتقويم والمتابعة: • تعاني أغلب بر امج التتمية المهنية مسن إهمال عملية التقويم و المتابعة بعد انتهاء

$$
\text { البرنامج التدريبي. }
$$

• سيادة الطابع الروتيني على عملية تقويم

$$
\text { تحصيل المتدربين. }
$$

• عدم در اسة تقارير البر امج للاستفادة من ملاحظاتها في تحسين بــر امج التتميــة

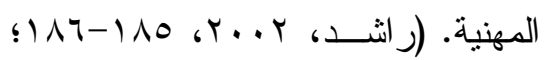

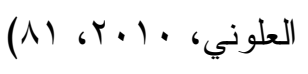

• نظرة المعلمين لبر امج التتميـــة المهنيـــة على أنها غير مجدية ومضيعة للوقت. • ضعف الكــــوادر الفنبـــة فــــي الإدار ات العامة لتدريب المعلمين و التــي تتـسم بالقدرة على تخطـ بــ وتتفيــذ وتقــــيم برنامج تدريبي فعال.

• عدم الإيمان بأهمية بر امج التتمية المهنية من جانــب العــاملين علــى تخطــيط

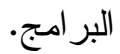

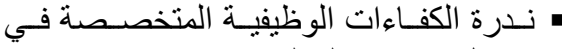

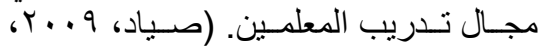

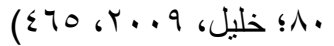

ج-معوقات تتعلق بنقص الإمكانـات المـاديــة والقنية: • تعاني بر امج التتمية المهنية من نقـص الإمكانات المادية كافتقار ها إلى الأبنيــة الصالحة للتدريب. ه افتقار معظم مر اكز التدريب إلى الكتب و المر اجع الحديثة. • صعوبة الحــصول علــى المعلومــات الإحصائية، التي تعين على وضع خطط التتمية المهنية. • قلة تو افر المطبوعات اللازمة للتدريب، ونـــدرة اســـتخدام الوســـائل التعليميـــة وتكنولوجيا التعليم. • ضعف الميز انيـــة المخصــصـة لتنميــة معلمي التربية الخاصة مهنيًا. (بــاقر ، 
V- Vرورة التتسيق بين وزارة التربيــة

و التعليم و الجهات المعنيـــة بالتتميـــة

المهنية على المسـتويين المركــزي ولهي

$$
\text { و المحلي. }
$$

1 - تحديد قائمة بمعايير معتمــدة للتتميــة

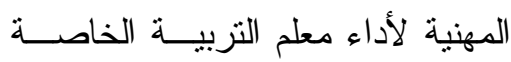

$$
\text { و اطلاعه عليها. }
$$

9- مر اجعة عناصر تقويم الأداء الوظيفي

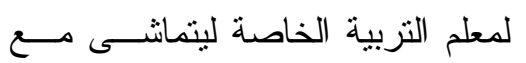

$$
\text { معايير التتمية المهنية. }
$$

ـ ا- التكامل بين مؤسسات إعــداد معلــــ

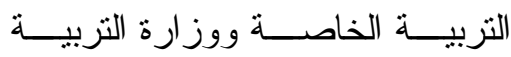

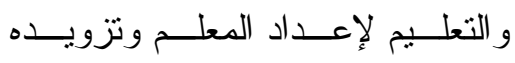

$$
\text { بالتغذية الر اجعة. }
$$

1 1 -إنذار المعلمين المقصرين و إعطــائهم

مهلة محدودة لتعويض القصور •

7 ا-تطبيق نظــام ماجسـتير الممارســـة

(الوظيفي) لمعلم التربيــة الخاصـــة.

(www.manhal.net)

IV

كل ما هو جديد في مجالاتهم العلميـــة

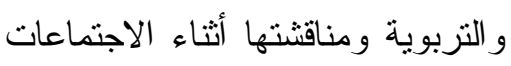

الفنية.

1 1-نشر نقافة التتمية المهنية بين المعلمين

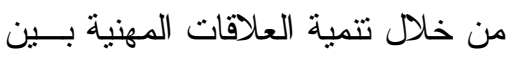

المعلمين وبيئتهم و المجتمع المحلــي.

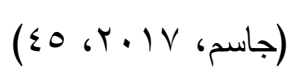

\section{رابعًا: متطلبـات التنميـة المهنيـة لمعلمي التربيـة}

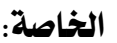

1- وضع خطة لتوفير الإمكانات المادية،

و البشرية التي تساعد على تتمية معلم

التربية الخاصة مهنيا، وتحقيق أهداف

العملية التعليمية.

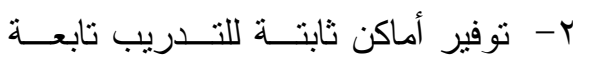

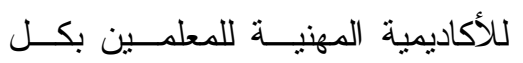

محافظة وبكل مركز .

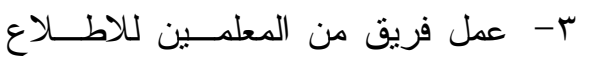

المستمر على أهم تجارب وخبـــرات

الدول المتقدمة فــي مجـــال التتميـــة

المهنية لمعلمــي التربيــة الخاصـــة،

وكيفية تغلبهم على العقبات التي تعوق

التمية المهنية.

ع- إنثاء جهـاز مـسئول عـن تـوفير

الوسائل التكنولوجية بمراكز التتميــة

$$
\text { المهنية وصيانتها. }
$$

0- صياغة قو انين ولو ائح تتظم العمل في وصيان

مجال التتمية المهنية لمعلمي التربيــة

$$
\text { الخاصة. }
$$

ا- - عمل جدول زمنــي يلـزمة الجهــات

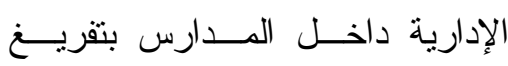

المعلمين فتزات ثابتة لحضور برامج دالادرية

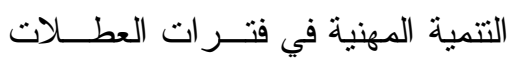

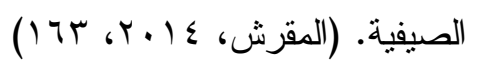


ضوء مدركاتهم عن احتياجاتهم التنريبية،

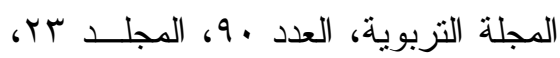
جامعة الكويت.

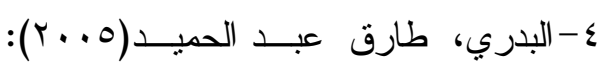
الإدارة الفاعلة للمعلم الناجح "الخــصائص و المهار ات"، دمشق، دار الإيمان.

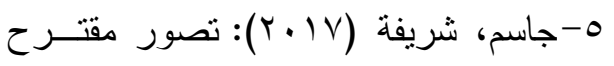

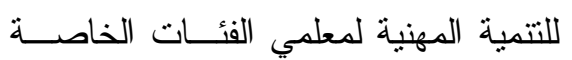
بدولة الكويت في ضوء الاتجاه العـالمي

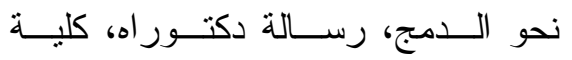
الدر اسات العليا للتربية، جامعة القاهرة.

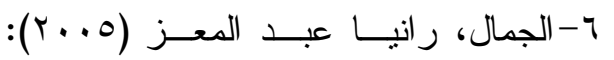

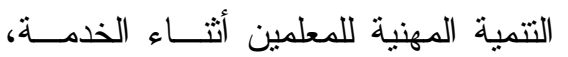
المؤتمر العلمي السادس بعنوان "التتميـــة

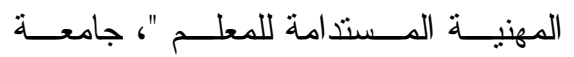

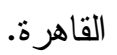

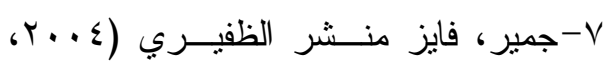
مارس): أهداف وطموحات نزبوية فئسي التعليم الإلكتروني، رسالة التربية، سلطنة عمان، العدد ؟ـ.

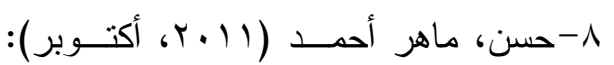
الاعتماد المهني وعلاقته بالتتمية المهنيـــة

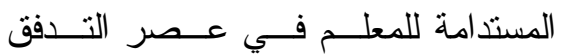

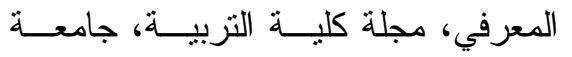
أسيوط، المجلد VY T، العدد (Y).

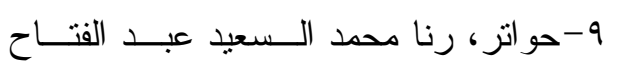

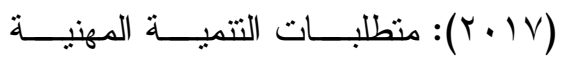

9 1 - الاستفادة من خبر ات الدول المتقدمسـة

في مجال التنمية المهنية لمعلم التربية الخاصة.

•r-جعل الوقت الذي يقضيه المعلم فـي بر امج التتمية المهنية جزءًا من أوقات التوفيه

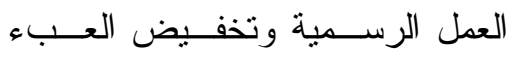
التدريسي الو اقع على عاتقه.

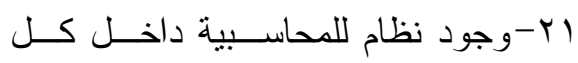
مدرسة، و إعطاء مدير المدرسة نسبة

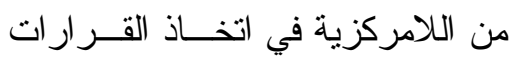
الخاصة بتحديد مستويات معلميه.

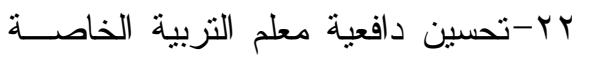
نحو التتمية المهنية من خلال تـوفير الحو افز المادية و المعنوية. بr-تفريغ المعلمين فترات ثابتة لحــضور بر امج التنمية المهنية.

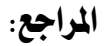
1-الأسطل، إير اهيم حامد، و الخالدي، فريال

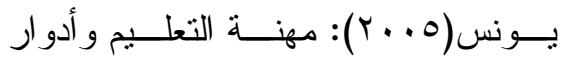
المعلم في مدرسة المستقبل، العـين، دار

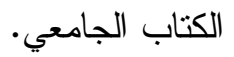

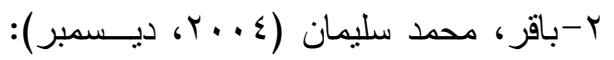
تدريب المعلمين - المعوقات و الحلـــول، مجلة التزبية، العدد (r) (I)، البحرين.

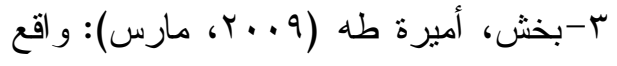
بر امج تدريب معلمي التربية الخاصة في المملكة العربية السعودية وتطويرها فـي لئي 


$$
\begin{aligned}
& \text { التزبوي فــي الــوطن العربــي. رؤى } \\
& \text { (- مستقبلية) مصر • }
\end{aligned}
$$

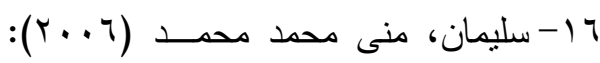

$$
\begin{aligned}
& \text { تصور مقترح لتدريب معلمي التربيـــة } \\
& \text { الخاصة في ضوء احتياجاتهم التدريبية }
\end{aligned}
$$

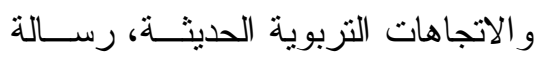

$$
\begin{aligned}
& \text { دكتور اه، كلية التربية، جامعة دمياط. }
\end{aligned}
$$

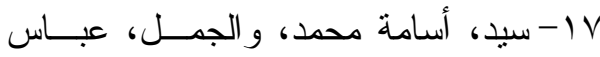

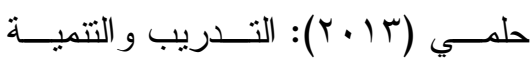

$$
\begin{aligned}
& \text { المهنية المستدامة، القاهرة، دار العلـــ } \\
& \text { و الإيمان للنشر و التوزيع. }
\end{aligned}
$$

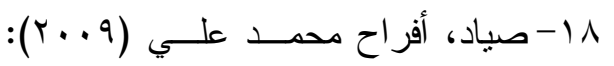

$$
\begin{aligned}
& \text { تطوير بر امج التتمية المهنية للمعلمـين } \\
& \text { على ضوء معايير الجودة والاعتمــاد، }
\end{aligned}
$$

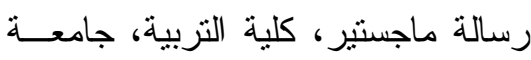

$$
\begin{aligned}
& \text { عين شمس. }
\end{aligned}
$$

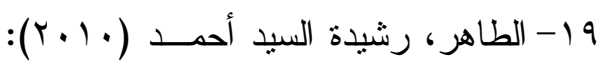

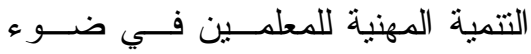

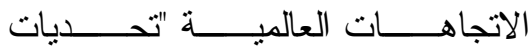

$$
\begin{aligned}
& \text { وطموحات"، الإسكندرية، دار الجامعــة }
\end{aligned}
$$

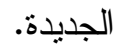

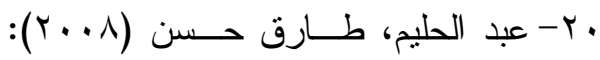

$$
\begin{aligned}
& \text { التتمية المهنية للمعلمين في مصر علي }
\end{aligned}
$$

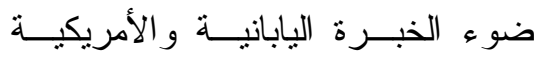

$$
\begin{aligned}
& \text { و الإنجليزية، القاهرة، دار العلوم. } \\
& \text { لمعلمات رياض الأطفال في مصر علـى }
\end{aligned}
$$

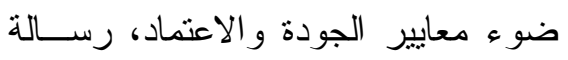

$$
\begin{aligned}
& \text { ماجستير ، كلية التزبية، جامعة دمياط. }
\end{aligned}
$$

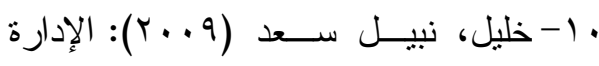

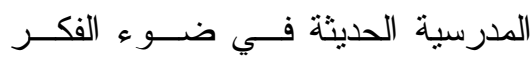

$$
\begin{aligned}
& \text { الإداري المعاصر ، القاهرة، دار الفجر. } \\
& \text { ا ا-دياب، إسماعيل محمد، و البنــا، عــادل }
\end{aligned}
$$

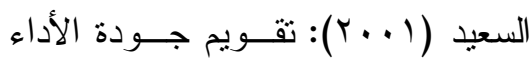

$$
\begin{aligned}
& \text { الجامعي، القاهرة، المكتبة المصرية. }
\end{aligned}
$$

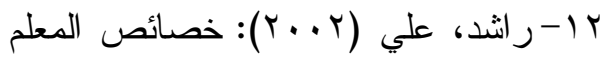

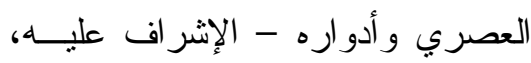

$$
\begin{aligned}
& \text { تدريبه، القاهرة، دار الفكر العربي. }
\end{aligned}
$$

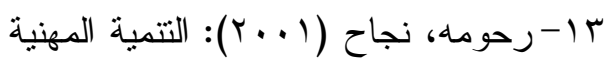

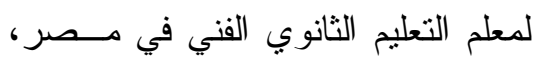

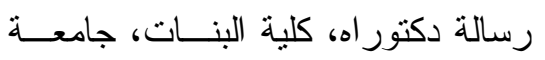

$$
\begin{aligned}
& \text { عين شمس. }
\end{aligned}
$$

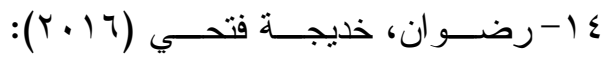

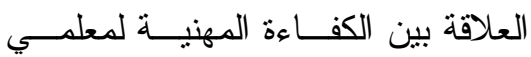

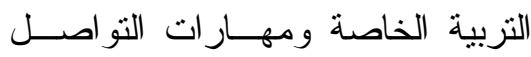

$$
\begin{aligned}
& \text { الكلي مع الأطفال ذوي الإعاقة العقلية، }
\end{aligned}
$$

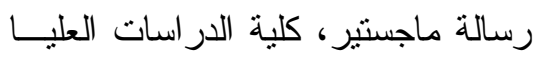

$$
\begin{aligned}
& \text { للتربية، جامعة القاهرة. }
\end{aligned}
$$




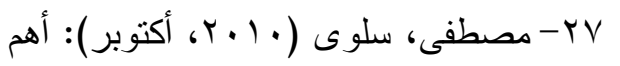

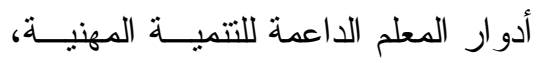

الثقافة و التتمية، مصر ، العدد(rV).

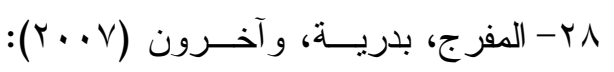

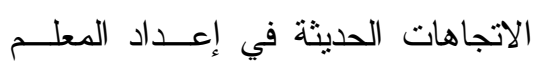

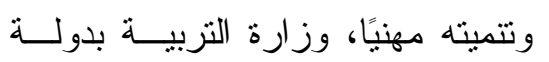

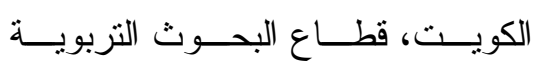

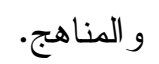

9 و- المقــرش، وفـــاء إبــر اهيم الحــسانين

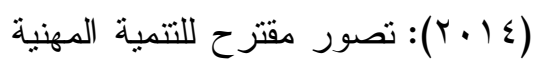
لمعلم الأطفال المعاقين عقليا في ضــــو هو بعض الاتجاهات التزبويـــة الحديثـــة، رسالة ماجستير، كلية رياض الأطفال، جامعة القاهرة.

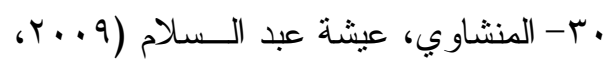
يوليو): أساليب التتمية المهنية المستدامة

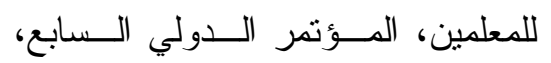

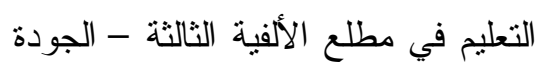

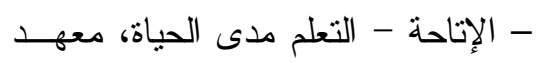
الدر اسات التربوية، جامعة القاهرة.

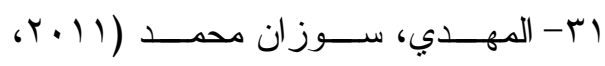
يوليو): التتمية المهنية للمعلمين في دول لون

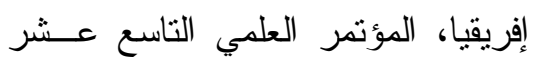
للجمعية المـصرية للتربيــة المقارنـــة و الإدارة التعليميـــة (التعلــيم و التتميـــة البشرية في دول قارة إفريقيا) - مصر .

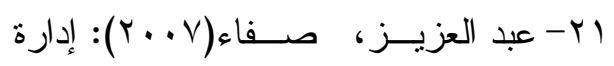
الفصل وتتمية المعلم، الإسكندرية، دار الجامعة الجديدة.

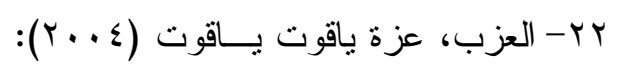

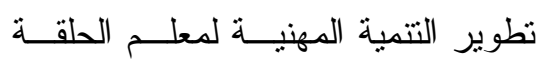
الأولى من مرحلة التعليم الأساسي فـي لئي

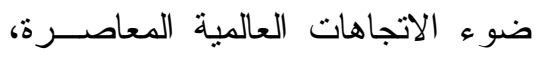
رسالة دكتور اه، كلية البنــات، جامعــة الجهات

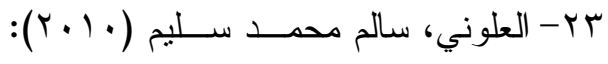

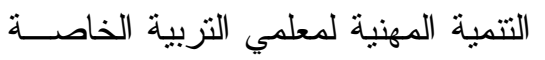

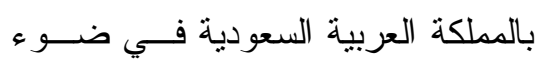
خبرات بعض الدول، رسالة دكتهـور اه،

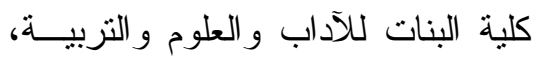
جامعة عين شمس.

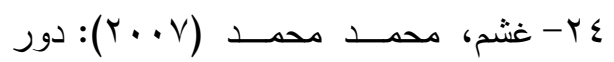

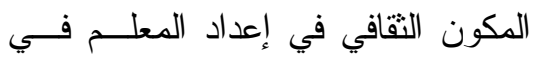

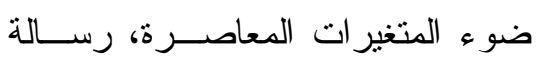
التربية، العدد (7 ( ).

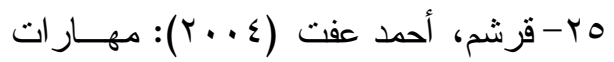
التــدريس لمعلمـي ذوي الاحتياجــات

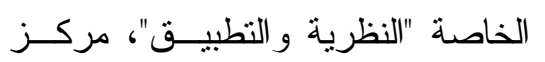
الكتاب للنشر ، القاهرة. TY - القمش، مصطفى، و الـسعايدة، نــاجي

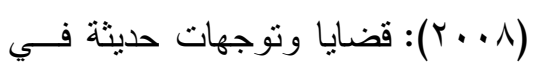
التربية الخاصة، دار المسيرة، عمان. 
staff Development, Vol.21, No. 3.

37- Hebert, L. (2007). Designing Online Professional Development for Teachers: Practice Related to Theory, The International Journal of Learning, C G publisher, Vol. 14, No.2.

38- O'Gorman, E., \& Drudy, S. (2011). Professional development for teachers working in special education/inclusion in mainstream schools: The views of teachers and other stakeholders.

39- Overbaugh, R., \& Lu, R. (2008). The impact of a federally funded grant on a professional development program: Teachers' stages of concern toward technology integration. Journal of computing in Teacher Education, 25(2).

40- Villegas- Reimers, E. (2003).

Teacher Professional development: An international review of the Literature. Paris: UNESCO: International Institute for Educational Planning.

41- www.manhal.net (27/11/2018).

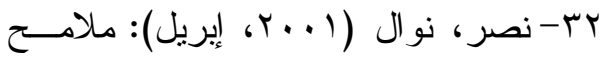

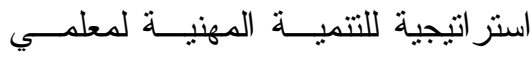

$$
\begin{aligned}
& \text { التربية الخاصة مجلة مستقبل التربيــة }
\end{aligned}
$$

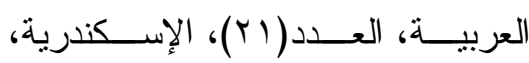

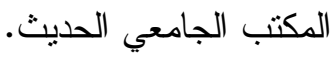

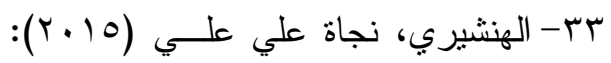

$$
\begin{aligned}
& \text { تطوير منظومة التتمية المهنية لمعلديسي }
\end{aligned}
$$

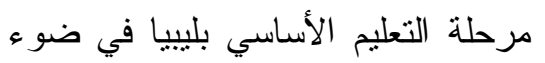

$$
\begin{aligned}
& \text { المتغيرات العالمية المعاصرة "تـصور }
\end{aligned}
$$

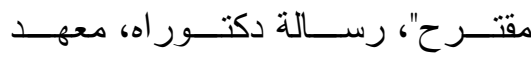

$$
\begin{aligned}
& \text { الدر اسات التربوية، جامعة القاهرة. }
\end{aligned}
$$

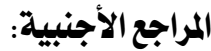

34- Chitiyo, M., Hughes, E. M., Changara, D. M., Chitiyo, G., \& Montgomery, K. M. (2017). Special education professional development needs in Zimbabwe. International Journal of Inclusive Education, 21(1).

35- Cook, J, A., Peker, D., (2009). Support Professional Development for Teachers through Discussions on Internet, A case study of A Group of Teachers Journal of APA Professional Development.

36- Dufour, R. (2000). Why Teach? American Journal of 